LonB Protease Is a Novel Regulator of Carotenogenesis Controlling Degradation of Phytoene Synthase in Haloferax volcanii

Cerletti, M

http://hdl.handle.net/10026.1/11854

10.1021/acs.jproteome.7b00809

Journal of Proteome Research

American Chemical Society

All content in PEARL is protected by copyright law. Author manuscripts are made available in accordance with publisher policies. Please cite only the published version using the details provided on the item record or document. In the absence of an open licence (e.g. Creative Commons), permissions for further reuse of content should be sought from the publisher or author. 
This is an accepted manuscript of an article published by ACS

Publications in Journal of Proteome Research (accepted February 17

2018) available at:

https://pubs.acs.org/doi/10.1021/acs.jproteome.7b00809 


\title{
LonB protease is a novel regulator of carotenogenesis controlling degradation of phytoene synthase in Haloferax volcanii
}

\author{
Micaela Cerletti ${ }^{a}$, Roberto Paggi ${ }^{a}$, Christian Troetschel ${ }^{b}$, María Celeste Ferrari ${ }^{a}$, Carina Ramallo \\ Guevara $^{\mathrm{b}}$, Stefan Albaum ${ }^{\mathrm{c}}$, Ansgar Poetsch ${ }^{\text {bd* }}$, Rosana De Castro ${ }^{\mathrm{a}^{*}}$ \\ ${ }^{*}$ Corresponding authors
}

\begin{abstract}
${ }^{a}$ Instituto de Investigaciones Biológicas, Universidad Nacional de Mar del Plata (UNMDP), Consejo Nacional de Investigaciones Científicas y Técnicas (CONICET), Funes 3250 4to nivel, Mar del Plata (7600), Argentina.

${ }^{\mathrm{b}}$ Plant Biochemistry, Ruhr University Bochum, 44801 Bochum, Germany

${ }^{\mathrm{c} B i o i n f o r m a t i c s ~ R e s o u r c e ~ F a c i l i t y, ~ C e n t e r ~ f o r ~ B i o t e c h n o l o g y ~(C e B i T e c), ~ B i e l e f e l d ~ U n i v e r s i t y, ~} 33615$

Bielefeld, Germany

${ }^{\mathrm{d}}$ School of Biomedical and Healthcare Sciences, Plymouth University, Plymouth PL4 8AA, UK
\end{abstract}

E-mail: decastro@mdp.edu.ar; ansgar.poetsch@ruhr-uni-bochum.de

Phone number: $+542234753030(12) ;+492343223633$

Key words: Membrane protease, proteome turnover, LonB substrates, Haloferax volcanii, phytoene synthase, Archaea. 


\begin{abstract}
The membrane protease LonB is an essential protein in the archaeon Haloferax volcanii and globally impacts its physiology. However, natural substrates of the archaeal Lon protease have not been identified. In this study the whole proteome turnover was examined in a $H$. volcanii LonB mutant under reduced and physiological protease levels. LC-MS/MS combined with stable isotope labeling was applied for the identification/quantitation of membrane and cytoplasm proteins. Differential synthesis and degradation rates were evidenced for 414 proteins in response to Lon expression. A total of 58 proteins involved in diverse cellular processes showed a degradation pattern (none/very little degradation in absence of Lon and increased degradation in presence of Lon) consistent with a LonB substrate, which was further substantiated for several of these candidates by pull-down assays. The most notable was phytoene synthase (PSY), the rate-limiting enzyme in carotenoid biosynthesis. The rapid degradation of PSY upon LonB induction in addition to the remarkable stabilization of this protein and hyperpigmentation phenotype in the Lon mutant strongly suggest that PSY is a LonB substrate. This work identifies for the first time candidate targets of the archaeal Lon protease and establishes proteolysis by Lon as a novel posttranslational regulatory mechanism of carotenogenesis.
\end{abstract}

\author{
ABBREVIATIONS \\ Bctr: bacterioruberin \\ DDM: dodecyl maltoside \\ DSP: dithiobis (succinimidyl propionate) \\ KO: knockout \\ LC-MS: liquid chromatography-mass spectrometry \\ OD: optical density \\ PSY: phytoene synthase
}


Trp: tryptophane

\section{INTRODUCTION}

All type of organisms change their proteome composition (quali and/or quantitatively) as a response to environmental and/or physiological signals. These changes are mainly the consequence of the combination of two independent processes: protein synthesis and degradation (protein turnover). Additionally, the proteome may be affected by posttranslational mechanisms, protein secretion and/or import from neighbor cells. Recent advances in proteomics techniques have facilitated the determination of the whole proteome turnover of a cell. One such approach combines stable isotope metabolic labeling with high-resolution mass spectrometry and bioinformatics tools. ${ }^{12}$ Although this technology has been successfully applied to examine the proteome turnover of microorganisms, ${ }^{3}$ to the best of our knowledge, the whole proteome turnover in Archaea has not been explored for any condition. Interestingly, this unusual group of prokaryotes mostly thrive in extreme habitats, thus, examination of the rate of synthesis/degradation of their proteome may give insight on the molecular mechanisms of their astonishing adaptation capability to adverse environmental conditions.

Proteolysis is a key process in cell physiology as it is needed for protein homeostasis, regulation of gene expression and precursor processing among other cellular events. Proteases localized at the cell membrane participate in a number of processes such as signal transduction, cell envelope biogenesis and protein secretion/processing. Their substrates are usually membrane-anchored or secreted proteins ${ }^{4}$ and include receptors, transporters, structural proteins and enzymes involved in metabolic or regulatory circuits. In contrast to soluble proteases, and likely due to the difficulties inherent to the biochemistry of membrane proteins, the biological function of membrane-associated proteases is less understood, being those from archaea the least characterized. ${ }^{5}$

The AAA+ proteases (proteasome, the ClpP family, HslUV, Lon and FtsH) eliminate damaged/unfolded proteins and control the level of regulatory and metabolic proteins in all cell types. ${ }^{6}$ 
Among these, only the metalloprotease FtsH is membrane-associated and occurs in most bacteria and eukaryotic organelles, however, it is absent from archaeal genomes. Interestingly, in Archaea the Lon protease is bound to the cell membrane by means of a hydrophobic fragment inserted in the AAA+ module, a feature that contrasts with the soluble Lon that occurs in most bacteria and eukaryotes. ${ }^{7}$ Compared to the soluble version of Lon proteases (LonA subfamily), little is known about the biological relevance of the membrane-intrinsic homolog that predominates in Archaea (LonB subfamily). Moreover, natural substrates of this protease have not been identified. Taking into account the unusual localization of the archaeal LonB, it is possible to speculate that it may play a central role in the turnover of membrane proteins and likely affects protein targets unique to these organisms. To begin addressing these questions, we first conducted a genetic approach in the model euryarchaeon Haloferax volcanii aiming to get mutant strains defective in the lon gene. The inability to get such mutants led us to the conclusion that LonB is an essential protease in this archaeon (and likely in other archaea as well). ${ }^{8}$ H. volcanii lon conditional mutants were constructed by introducing the trp-regulatable tryptophanase promoter ptnaA by homologous recombination. ${ }^{9}$ Suboptimal Lon protease synthesis (in absence of trp) produced $H$. volcanii cells affected in growth rate (reduced), cell shape, membrane lipid composition (increased carotenoid content) and sensitivity to several antibiotics. ${ }^{8}$

Assessment of the in vivo degradome of a protease is a challenging enterprise but it is essential to fully understand its biological function. For substrate-processing ${ }^{10}$ and substrate-degrading proteases, proteomics has been developed. Regarding the latter, some examples in microorganisms include global proteome analysis of protease deficient mutants by 2D polyacrylamide gel electrophoresis (yeast mitochondria Pim1/Lon; H. volcanii proteasome component PanA) ${ }^{11} 12$ and trapping approaches (E. coli ClpXP/FtsH; Caulobacter crescentus ClpP). ${ }^{13} 1415$ Determination of the proteome turnover by means of stable isotope metabolic labeling combined with LC-MS has been applied to study the degradome of soluble proteases of bacteria $(S \text {. aureus } \mathrm{ClpP})^{113}$, but to the best of our knowledge it has not been used for membrane-associated proteases of prokaryotes. 
To evaluate the physiological relevance of LonB in Archaea and as a preliminary strategy to discover its potential targets, a shotgun proteomics approach was conducted comparing the whole proteomes of wt and conditional mutant (HVLON3) with reduced Lon content in $H$. volcanii. This study revealed that LonB has a global impact on the physiology of this archaeon affecting the concentration of proteins involved in various cellular processes. ${ }^{16}$ Interestingly, phytoene synthase (PSY), a key enzyme in carotenoid biosynthesis, remarkably increased in amount in HVLON3 (50-60 fold). Such increase in the concentration of PSY correlated with the hyperpigmented phenotype of the H. volcanii lon mutants. ${ }^{8}$ Considering that variations in the concentration of a given protein may be attributed to changes in its rate of synthesis and/or degradation, determination of protein turnover was necessary to address which process was affected.

To identify natural substrates of LonB, in this study, the $H$. volcanii proteome turnover was determined in the conditional lonB mutant under reduced (- trp) and nearly physiological ( + trp) protease levels by means of the heavy isotope metabolic labeling approach coupled to LC-MS analysis. Pull-down assays were also performed as a validation strategy.

\section{EXPERIMENTAL PROCEDURES}

\section{Strains and culture conditions}

Microorganisms used in this study are indicated in Table S1. Escherichia coli strains were grown at 37 ${ }^{\circ} \mathrm{C}$ in Luria-Bertani medium supplemented with ampicillin $\left(100 \mu \mathrm{g} \mathrm{ml}^{-1}\right)$ or kanamycin $\left(50 \mu \mathrm{g} \mathrm{ml} \mathrm{l}^{-1}\right)$ when needed. E. coli DH5 $\alpha$ and GM33 were used for routine cloning and transformed by the $\mathrm{CaCl}_{2}$ method. ${ }^{17}$

H. volcanii $\mathrm{H} 26$ and mutant strain HVLON3, previously constructed in our laboratory, ${ }^{8}$ were used in this study. HVLON3 is a conditional expression mutant which contains the tryptophan (trp)-regulated promoter (ptnaA) ${ }^{9}$ inserted upstream of the lon gene in H. volcanii H26 chromosome. This strain synthesizes suboptimal amounts of LonB protease in absence of trp in the culture medium. H. volcanii strains were grown in modified minimal medium (Hv-Min) with glucose $10 \%$ instead of carbon source at 
$42{ }^{\circ} \mathrm{C} 150 \mathrm{rpm}^{18}$ in presence of 5-fluoroorotic acid (5-FOA) $\left(50 \mu \mathrm{g} \mathrm{ml}^{-1}\right)$, uracil $\left(10-50 \mu \mathrm{g} \mathrm{ml}^{-1}\right)$ and/or $\operatorname{trp}(0.1-2 \mathrm{mM})$ as needed. Cell growth was monitored by measuring the optical density of the cultures at $600 \mathrm{~nm}\left(\mathrm{OD}_{600}\right)$.

To analyze the effect of LonB on $H$. volcanii proteome synthesis, HVLON3 cells were first grown in Hv-Min in absence of $\operatorname{trp}$ with ${ }^{14} \mathrm{~N}$ as the sole nitrogen source $\left({ }^{14} \mathrm{NH}_{4} \mathrm{Cl}\right)$. When the cultures reached the early exponential phase $\left(\mathrm{OD}_{600} 0.3\right)$ the cells were harvested by centrifugation $\left(6500 \times \mathrm{g}, 20 \mathrm{~min}, 4^{\circ} \mathrm{C}\right)$, washed with saline buffer $(30 \mathrm{mM}$ Tris- $\mathrm{HCl} \mathrm{pH} \mathrm{7;2.5} \mathrm{M} \mathrm{NaCl})$ and suspended in fresh Hv-Min containing ${ }^{15} \mathrm{NH}_{4} \mathrm{Cl}$ (pulse). The culture was then split in two halves, one half was kept in absence of trp and the other was supplemented with $0.1 \mathrm{mM}$ trp to induce LonB expression to endogenous levels. Samples were taken before (T0) and 2 (T1), 5 (T2), 8 (T3) and $11 \mathrm{~h}$ (T4) after the pulse.

$\mathrm{A}{ }^{13} \mathrm{C}$ internal standard was generated to normalize ${ }^{14} \mathrm{~N}$-labelled protein abundances across samples and calculate degradation rates over time $\left({ }^{14} \mathrm{~N} /{ }^{13} \mathrm{C}\right.$ ratios). A colony of the mutant strain HVLON3 was inoculated into Hv-Min containing ${ }^{13} \mathrm{C}$-glucose as the sole carbon source (preculture) and the culture was grown as described until late exponential phase $\left(\mathrm{OD}_{600} 0.8\right)$. Then, $1 / 100$ of this culture was transferred to fresh ${ }^{13} \mathrm{C}$ medium (twice) to eliminate any remnants of ${ }^{12} \mathrm{C}$. Finally this culture was used to inoculate 500 $\mathrm{ml}$ of $\mathrm{Hv}-\mathrm{Min}$ containing ${ }^{13} \mathrm{C}$-glucose. The culture was grown to early exponential phase $\left(\mathrm{OD}_{600} 0.3\right)$ and then split in two halves. One half was kept in absence of trp and the other was supplemented with $0.1 \mathrm{mM}$ trp. Samples were withdrawn after 2 and $8 \mathrm{~h}$ and pooled $\left({ }^{13} \mathrm{C}\right.$ standard).

\section{Preparation of cytoplasm and membrane fractions}

The culture samples containing ${ }^{14} \mathrm{~N} /{ }^{15} \mathrm{~N}$ or ${ }^{13} \mathrm{C}$ were treated with $0.125 \mathrm{M}$ EDTA pH 6.8 for 30 min at $37{ }^{\circ} \mathrm{C}$ to remove the S-layer glycoprotein and enrich the less abundant membrane proteins. Cells were harvested by centrifugation $\left(10,000 \times \mathrm{g}, 10 \mathrm{~min}, 4{ }^{\circ} \mathrm{C}\right)$, suspended in $100 \mathrm{mM} \mathrm{HCl}-$ Tris $(\mathrm{pH} 7.5), 2 \mathrm{M}$ $\mathrm{NaCl}$ containing protease inhibitors ( $1 \mathrm{mM}$ PMSF, $1 \mu \mathrm{M}$ E-64, $5 \mathrm{mM}$ EDTA) and disrupted by sonication $(30 \mathrm{~s} \mathrm{x} 6,60 \mathrm{~W})$. Cytoplasm and membrane proteins were extracted and quantified according to Cerletti et 
al. ${ }^{16}$ To determine protein degradation rates, the ${ }^{14} \mathrm{~N} /{ }^{15} \mathrm{~N}$ protein samples were spiked with the ${ }^{13} \mathrm{C}$ internal standard at a $1: 1(\mathrm{w} / \mathrm{w})$ ratio.

\section{Electrophoresis in polyacrylamide gels (SDS-PAGE)}

Protein samples form synthesis $\left({ }^{14} \mathrm{~N} /{ }^{15} \mathrm{~N}\right)$ and degradation assays $\left({ }^{14} \mathrm{~N} /{ }^{15} \mathrm{~N}+{ }^{13} \mathrm{C}\right)$ were precipitated with acetone $\left(\mathrm{ON}, 4{ }^{\circ} \mathrm{C}\right)$ and washed three times with $80 \%$ acetone and once with $100 \%$ acetone. Protein samples were loaded $(\sim 30 \mu \mathrm{g}$ per lane) into $10 \%(\mathrm{v} / \mathrm{v})$ polyacrylamide gels, concentrated into one protein band in the separation gel and visualized with Coomassie Brilliant Blue as described in Cerletti et al. ${ }^{16}$

\section{In-gel tryptic digestion}

Protein bands were excised from the gels and cut into small cubes $($ ca. $1 \times 1 \mathrm{~mm})$ which were completely destained. ${ }^{19}$ Gel pieces were dried by incubation with $100 \%$ acetonitrile for 10 min at room temperature and then incubated with $50 \mathrm{mM}$ DTT in $25 \mathrm{mM} \mathrm{NH}_{4} \mathrm{HCO}_{3}$ for 30 min at $60{ }^{\circ} \mathrm{C}$ to reduce proteins disulfide bonds. The gel pieces were dried again with acetonitrile and proteins were alkylated by treating the gel pieces with $50 \mathrm{mM}$ iodoacetamide in $25 \mathrm{mM} \mathrm{NH}_{4} \mathrm{HCO}_{3}$ for $1 \mathrm{~h}$ at room temperature in darkness. Proteins were digested with trypsin and the peptides eluted according to Cerletti et al. ${ }^{16}$ The extracted peptides were dried using a SpeedVac, re-suspended in $20 \mu \mathrm{l}$ of buffer A $(0.1 \%$ formic acid in water, ULC/MS, Biosolve, Netherlands) by sonication for $10 \mathrm{~min}$ and transferred to LC-MS grade glass vials $(12 \times 32 \mathrm{~mm}$ glass screw neck vial, Waters, USA). Each measurement was performed with $8 \mu \mathrm{l}$ of sample.

\section{One-dimensional $n L C$-ESI-MS/MS}

An UPLC HSS T3 column $(1.8 \mu \mathrm{m}, 75 \mu \mathrm{m} \times 150 \mathrm{~mm}$, Waters, Milford, MA, USA) and an UPLC Symmetry C18 trapping column (5 $\mu \mathrm{m}, 180 \mu \mathrm{m} \times 20 \mathrm{~mm}$, Waters, Milford, MA, USA) for LC as well as a PicoTip Emitter (SilicaTip, $10 \mu \mathrm{m}$ i.d., New Objective, Woburn, MA, USA) were used in combination with the nanoACQUITY gradient UPLC pump system (Waters, Milford, MA, USA) coupled to an LTQ 
Orbitrap Elite mass spectrometer (Thermo Fisher Scientific Inc., Waltham, MA, USA). For elution of the peptides a linear gradient with increasing concentration of buffer B $(0.1 \%$ formic acid in acetonitrile, ULC/MS, Biosolve, Netherlands) from $2 \%$ to $30 \%$ within 161 min was applied, followed by a linear gradient from $30 \%$ to $85 \%$ acetonitrile concentration within $5.5 \mathrm{~min}(0-5.1 \mathrm{~min}$ : $2 \%$ buffer $\mathrm{B}$; $5.1-10 \mathrm{~min}$ : 5\% buffer B; 10-161 min: 30\% buffer B; 161-166.5 min: 85\% buffer B; $166.5-180$ min: 2\% buffer B) at a flow rate of $400 \mathrm{~nL} \min ^{-1}$ and a spray voltage of $1.5-1.8 \mathrm{kV}$. The column was re-equilibrated at $2 \%$ buffer B within $15 \mathrm{~min}$. The analytical column oven was set to $55^{\circ} \mathrm{C}$ and the heated desolvation capillary was set to $275{ }^{\circ} \mathrm{C}$. The LTQ Orbitrap Elite was operated by instrument method files of Xcalibur (Rev. 2.1.0) in positive ion mode. The linear ion trap and Orbitrap were operated in parallel, i.e. during a full MS scan on the Orbitrap in the range of $150-2000 \mathrm{~m} / \mathrm{z}$ at a resolution of 240,000, MS/MS spectra of the 20 most intense precursors (from most intense to least intense) were detected in the ion trap. The relative collision energy for rapid collision-induced dissociation (rCID) was set to 35\%. Dynamic exclusion was enabled with a repeat count of 1 and 60 seconds exclusion duration window. Singly charged and ions of unknown charge state were rejected from MS/MS.

\section{Protein identification and quantification}

MS data search was performed by SEQUEST ${ }^{20}$ algorithm embedded in Proteome Discoverer 1.4 (Thermo Electron (C) 2008-2012) searching against the complete proteome database of $H$. volcanii DS2 (4035 entries) exported from the Halolex database ${ }^{21}$ on $9 / 24 / 2013$. The mass tolerance for precursor ions and fragment ions was set to $6 \mathrm{ppm}$ and 0.4 Da, respectively. Only tryptic peptides with up to two missed cleavages were accepted. As static peptide modification the carbamidomethylation of cysteine and as variable peptide modification the oxidation of methionine as well as the conversion of glutamine (Gln) to pyro-glutamate (pyro-glu) at any N-terminus were admitted. The false discovery rate (FDR) was determined with the percolator validation in Proteome Discoverer 1.4 and the q-value was set to $1 \% .{ }^{22}$ For protein identification the mass spec format-(msf)-files were filtered with peptide confidence "high" and two unique peptides per protein. Additionally protein grouping options were enabled as default, which 
means consider only PSMs with confidence at least "medium" and consider only PSMs with delta CN better than 0.15 .

ExcelTM files (Microsoft Corporation, Redmond, WA, USA) were generated from the corresponding

${ }^{14} \mathrm{~N}$ msf-files to be used subsequently in QuPE ${ }^{23}$ (https://qupe.cebitec.uni-bielefeld.de/QuPE/app). This bioinformatics platform allows the quantification of stable isotope labeled samples and can determine the proteins synthesis and degradation rates using the ${ }^{14} \mathrm{~N} /{ }^{15} \mathrm{~N}$ and ${ }^{14} \mathrm{~N} /{ }^{13} \mathrm{C}$ abundance ratios, respectively. QuPE also allows for the statistical evaluation and visualization of the data. The quantification method and subsequent processing used is described in Trotschel et al. ${ }^{2}$ To plot the synthesis data the reciprocal ratios were used.

In vivo crosslinking assays

H. volcanii $\mathrm{H} 26$ (wt strain) was grown in Hv-Min medium to exponential phase $\left(\mathrm{OD}_{600} \sim 0.6\right)$. Briefly, the cells were harvested by centrifugation $(10,000 \times \mathrm{g} 15 \mathrm{~min})$, washed and suspended in saline phosphate buffer $(0.1 \mathrm{M}$ phosphate $\mathrm{pH} 7.2,2 \mathrm{M} \mathrm{NaCl})$ to a final $\mathrm{OD}_{600} \sim 2.5$. The crosslinkers $\mathrm{DSP}$ and formaldehyde were added to a final concentration of $1 \mathrm{mM}$ and $1 \%(\mathrm{v} / \mathrm{v})$, respectively. For DSP the reaction was incubated at room temperature for $2 \mathrm{~h}$ and stopped by incubation with $100 \mathrm{mM}$ Tris- $\mathrm{HCl} \mathrm{pH}$ 7.5 for $15 \mathrm{~min}$. For formaldehyde the reaction was incubated at room temperature for $10 \mathrm{~min}$ and stopped by adding glycine to $100 \mathrm{mM}$. After the crosslinking assay, the cells were harvested, washed and suspended in saline phosphate buffer containing protease inhibitors $(1 \mathrm{mM}$ PMSF, $1 \mu \mathrm{M}$ E-64, $5 \mathrm{mM}$ EDTA) and disrupted by sonication (30 s x 6, $60 \mathrm{~W})$. Cell debris were removed by centrifugation (10,000 x g $20 \mathrm{~min})$ and the membranes pelleted $\left(100,000 \times \mathrm{g}, 2 \mathrm{~h}, 4{ }^{\circ} \mathrm{C}\right)$ and washed with the same buffer $\left(100,000 \times \mathrm{g}, 30 \mathrm{~min}, 4^{\circ} \mathrm{C}\right)$. Membrane proteins were extracted by incubating in $1 \mathrm{X}$ PBS containing $1 \%$ dodecyl maltoside (DDM) for $1 \mathrm{~h}$ at $42{ }^{\circ} \mathrm{C}$ and then subjected to immunoprecipitation (see below). Protein concentration was measured by the bicinchoninic acid (BCA) assay.

Immunoprecipitation of HvLon-interacting proteins 
The HvLonB-interacting protein complexes were immunoprecipitated with anti-NmLon polyclonal antibodies conjugated to Protein A-Sepharose beads CL-4B (GE Healthcare). Anti-NmLon rabbit polyclonal antibodies were raised in our laboratory against the Natrialba magadii LonB protease and previously used. ${ }^{24}$ Briefly, anti-NmLon antibody $(10 \mu 1)$ was added to the membrane protein extract $(\sim$ $500 \mathrm{ng}$ ) and rotated for $2 \mathrm{~h}$ at $4{ }^{\circ} \mathrm{C}$. The same assay was performed using the anti-Nep (extracellular $N$. magadii protease) as negative control (no binding of HvLonB). Afterwards, the bead slurry (30 $\mu$ l) was added to the extract and rotated overnight at $4{ }^{\circ} \mathrm{C}$. Then, the beads were washed 3 times with $1 \mathrm{X}$ PBS containing $0.05 \%(\mathrm{v} / \mathrm{v})$ DDM, with $1 \mathrm{X}$ PBS and 3 times with $100 \mathrm{mM}$ ammonium hydrogen carbonate (AMBIC). To digest the bead-bound proteins, $10 \mu \mathrm{l}(10 \mathrm{ng} / \mu \mathrm{l})$ of trypsin in $100 \mathrm{mM}$ AMBIC was added to the washed beads and incubated overnight at $37^{\circ} \mathrm{C}$ with agitation. Then, another $10 \mu \mathrm{l}$ of trypsin were added and incubated for $4 \mathrm{~h}$ at $37^{\circ} \mathrm{C}$. The supernatant (peptide mix) was recovered; formic acid was added to $5 \%(\mathrm{v} / \mathrm{v})$ final concentration and dried in Speedvac. The peptides were suspended in $100 \mu \mathrm{l}$ Buffer A, desalted by zip-tipping with self-made tips containing C18 membranes and analyzed by MS as described above. Proteins were identified and quantified with MaxQuant version 1.5.3.17 using the LFQ algorithm. The parameters were set as described in Kaur et al.; ${ }^{25}$ threshold Andromeda scores for unmodified and modified peptides were 0 and 40 , respectively.

\section{Experimental design and statistical rationale}

For the pulse-chase experiments three biological replicates were performed to ascertain statistical significance. There were 20 experimental conditions: membrane and cytoplasm, 5 time points (T0 only for degradation), plus and minus trp. The calculated abundance ratios $\left({ }^{14} \mathrm{~N} /{ }^{15} \mathrm{~N}\right.$ and $\left.{ }^{14} \mathrm{~N} /{ }^{13} \mathrm{C}\right)$ for each protein were compared between the minus and plus Lon conditions for all time points using ANOVA implemented in QuPE and $p$-values $\leq 0.05$ were considered significant. Ratios were plotted to ascertain normal distribution. The distribution of abundance ratios over time (boxplots) and the linear regression slopes for each protein with significant $p$-values were observed to determine whether they had faster/slower synthesis/degradation rates in presence of Lon. 
A pull-down assay using anti-NmLon antibodies was used to validate potential LonB targets. Four biological replicates were performed. The polyclonal antibody anti-Nep was used as negative control to detect unspecific binding to antibody and beads. Student's t-test function implemented in Perseus 1.5.5.3 was used to compare the protein LFQ intensities from the anti-NmLon and non-specific antibody essays. FDR was set to 0.05 using the permutation of data between samples implemented in Perseus (250 permutations, $\mathrm{S} 0=0.1$ ). Missing values were replaced with the lowest intensity value (13). Proteins that were found exclusively or significantly increased (FDR $\leq 0.05$ ) with anti-NmLon were considered to interact with the LonB protease. In addition we eliminated any protein that contained an AAA domain as the NmLon antibody might exhibit affinity against them. A trapping approach with inactivated LonB could not be performed in account of LonB being an essential protease in $H$. volcanii.

\section{Bacterioruberin determination}

Cells were suspended in acetone/methanol (1:1), incubated $30 \mathrm{~min}$ at room temperature and centrifuged. The content of bacterioruberins (bctr) was determined by measuring the optical density of the supernatant at $471 \mathrm{~nm}(\lambda \max$ of our extract), using GeneQuant 1300 spectrophotometer (GE Healthcare Bio-Sciences Corp., Piscataway, NJ, USA).

\section{Construction of crtB and lonB deletion mutants}

The crtB (HVO_2524) gene encoding the enzyme PSY was deleted from the chromosome of $H$. volcanii wt and HVLON3 strains by the pyrE2-based pop-in/pop-out method. ${ }^{9}$ Briefly, 700 bp of genomic DNA flanking the 5'- and 3'- ends of the target gene $c r t B$ was amplified using primer pairs PSYup_Fw/Rv and PSYdw_Fw/Rv (Table S1) and used as template for a second amplification with primers PSYup_Fw and PSYdw_Rv. The resulting UP-DW fragment was cloned into the TOPO-blunt vector and subsequently into the suicide plasmid pTA131 using EcoRI. The DNA fragment was sequenced and used as template for homologous recombination with the $H$. volcanii genome. Transformants were screened for integration in the absence of uracil ( $\mathrm{Hv}-\mathrm{Ca}$ ura-) and then for excision of the plasmid in 5-FOA. Deletion from the 
chromosome was confirmed by observing the pigmentation of the clones (deletion=white colonies) and by PCR using primers specific or external to the coding region. The $\Delta c r t B$ strain was subjected to the popin/pop-out protocol to delete the lon gene following the procedure in Cerletti et al. ${ }^{8}$

\section{RNA isolation and RT-PCR}

Total RNA was isolated from $H$. volcanii H26 and HVLON3 with Trizol reagent (Invitrogen) from exponential phase cultures. RNA was treated with RNase-free RQ1 DNase (Promega) and absence of contaminating DNA was assessed by PCR amplification with primers for the 7S RNA gene (archaeal signal recognition particle RNA). The cDNA synthesis was performed using $4 \mu \mathrm{g}$ DNA-free RNA and 0.5 $\mu \mathrm{g}$ of random arbitrary primers (RAP-PCR) as described in Paggi et al. ${ }^{26}$ The cDNA (200 ng) was used as template for RT-PCR amplification of PSY $(c r t b)$ and hypothetical protein HVO_A0039 using primers described in Table S1. PCR conditions for HVO_A0039 and PSY were $94{ }^{\circ} \mathrm{C} 2 \mathrm{~min} / 26-30$ cycles $\left(94{ }^{\circ} \mathrm{C}\right.$ $\left.30 \mathrm{~s}, 48{ }^{\circ} \mathrm{C} 1 \mathrm{~min}, 72{ }^{\circ} \mathrm{C} 30 \mathrm{~s}\right) / 72{ }^{\circ} \mathrm{C} 5 \mathrm{~min}$ and $94{ }^{\circ} \mathrm{C} 2 \mathrm{~min} / 32$ cycles $\left(94{ }^{\circ} \mathrm{C} 30 \mathrm{~s}, 60{ }^{\circ} \mathrm{C} 1 \mathrm{~min}\right.$ and $72{ }^{\circ} \mathrm{C}$ $30 \mathrm{~s}) / 72{ }^{\circ} \mathrm{C} 5 \mathrm{~min}$, respectively. The expression of the $7 \mathrm{~S}$ RNA gene was used as an internal control to normalize the expression level of the target genes.

\section{RESULTS}

\section{LonB has a global effect on $\boldsymbol{H}$. volcanii proteome turnover}

In this work we aimed to identify biological targets of the membrane-associated LonB protease in archaeal cells. To this end, we examined the proteome turnover in a conditional LonB mutant (HVLON3) of the model euryarchaeon H. volcanii under reduced (- trp, denoted as - Lon) and nearly physiological (+ trp, denoted as + Lon) LonB levels. HVLON3 was initially grown in minimal medium containing ${ }^{14} \mathrm{NH}_{4} \mathrm{Cl}$ as nitrogen source in absence of trp and then switched to ${ }^{15} \mathrm{~N}$-medium with/without trp ( \pm Lon) to monitor

${ }^{15} \mathrm{~N}$-label incorporation into newly synthesized proteins over time. In parallel, degradation of ${ }^{14} \mathrm{~N}-$ labeled proteins was estimated by comparing different time points of this culture via an internal standard grown on 
${ }^{13} \mathrm{C}$-glucose (Figure S1). Protein samples (membrane and cytoplasm fractions) were processed by SDSPAGE, digested with trypsin and analyzed by LC-MS/MS. Proteins were identified with Sequest and protein turnover as well as statistical analysis was achieved with QuPE. ${ }^{2}$

Using this approach, 1801 proteins from 4035 predicted for the $H$. volcanii genome ${ }^{21}$ were identified (45\% proteome coverage). Table 1 summarizes the number of identified, quantified and differential proteins (synthesis and degradation) in each experiment ( \pm Lon) and cellular faction.

\subsection{Protein synthesis}

To assess the effect of LonB deficiency on the overall protein synthesis, we examined the distribution of all calculated abundance ratios $\left({ }^{14} \mathrm{~N} /{ }^{15} \mathrm{~N}\right)$ for both conditions $( \pm$ Lon) over time. As expected, we obtained evidence of de novo synthesis of LonB when trp was added to the medium, based on the detection of an increasing number of ${ }^{15} \mathrm{~N}$ peptides in this condition (Figure S2A, table). Moreover, Western blot analysis showed that LonB was expressed at nearly physiological levels $1 \mathrm{~h}$ after addition of trp (Figure S2A). The ${ }^{15} \mathrm{~N}$ incorporation rate was higher in absence of Lon (Figure S2B). We speculate that the increase in the overall protein degradation rate after inducing Lon synthesis (see below) could lead to an increase in the free amino acids pool available for protein synthesis and, in turn, a decrease in the uptake of ${ }^{15} \mathrm{~N}$. Consistent with this hypothesis, several amino acids biosynthetic enzymes showed reduced synthesis when LonB expression was stimulated (Table S2).

Overall protein synthesis rates appeared very similar in both experimental conditions ( \pm Lon), however, statistical analysis (ANOVA and linear regression) (Figure S4), indicated that in the membrane fraction protein synthesis was significantly lower ( $p$-value 5.83E-07) in the + Lon (slope $=-0.32$ ) compared to the - Lon condition (slope $=-0.34$ ). Differential synthesis rates were evidenced for 225 proteins distributed in both cellular fractions (Table S3). While proteins related to translation, amino acids, co-enzyme, nucleotide and energy metabolism showed a decrease in synthesis when LonB expression was induced, those involved in transcription, environmental information processing and lipid metabolism displayed an increase in synthesis under this condition (Figure S3). 


\subsection{Protein degradation}

To assess the incidence of LonB on the degradation of $H$. volcanii proteome, we analyzed the ${ }^{14} \mathrm{~N} /{ }^{13} \mathrm{C}$ abundance ratios for the \pm Lon conditions over time. ANOVA and linear regression analysis (Figure S5) indicated that the overall proteome degradation rate was significantly higher at physiological Lon concentrations in both the membrane ( $p$-value: $1.6 \mathrm{E}-11)$ and cytoplasm ( $p$-value: $2.20 \mathrm{E}-16)$ (slopes \pm Lon: $-0.121 /-0.116$ and $-0.231 /-0.159$ for membrane and cytoplasm fractions, respectively).

To identify proteins with remarkable degradation rates, the calculated protein degradation ratios were normalized using the median of all the values collected for each condition and time point. This procedure revealed 291 proteins (including cytoplasm and membrane fractions) that showed differential degradation rates upon LonB induction (Table S4).

\section{LonB has different effects on its target proteins}

To better understand the physiological significance of the proteome turnover analysis in response to LonB, we examined the correlation between the differential synthesis/degradation rates and the changes in protein abundance for specific proteins reported in our previous work that compares the differential subproteome of the HVLON3 mutant vs the parental H26 strain. ${ }^{16}$ In addition, an in vivo crosslinking assay coupled to immunoprecipitation with anti-Lon antibody was performed in the H26 wt strain to detect interactions between LonB and its endogenous targets. Taking all these data into account, we classified these proteins in different categories (Table 2).

\subsection{LonB-dependent synthesis}

Several proteins that showed LonB-dependent synthesis correlated accordingly with the changes in protein amounts observed in HVLON3 (Table 2, Figure 1). For instance, the cellular content of HVO_A0039, encoding a membrane protein of unknown function, increased by up to 320 fold in 
HVLON3. ${ }^{16}$ The degradation pattern of this protein was independent of LonB (its degradation rate was not differential), however, its synthesis stopped when LonB expression was induced (Figure 1). To further this observation, the mRNA level of HVO_A0039 was compared in HVLON3 mutant vs the parental H26 strain. While the specific HVO_A0039 transcript was almost undetectable in H26, its level dramatically increased in HVLON3 (Figure S6). Altogether these results show that the protein encoded by HVO_A0039 is not a LonB substrate but its synthesis is highly regulated (negatively) by this protease. Other proteins with a similar pattern (reduced synthesis in + Lon/increased protein amount in HVLON3) were ABC transporter components of LolDCE lipoprotein release factor (HVO_2163 and HVO_2165), cobyrinic acid a,c-diamide synthase (HVO_A0487) and conserved hypothetical proteins (HVO_2519, HVO_A0012, HVO_A0406).

On the contrary, some proteins decreased in amount in HVLON3 and their synthesis was stimulated in response to LonB. This means that LonB positively controls their synthesis (e.g. transcription initiation factor TFB, HVO_0795; GFO oxidoreductase, HVO_C0069). 

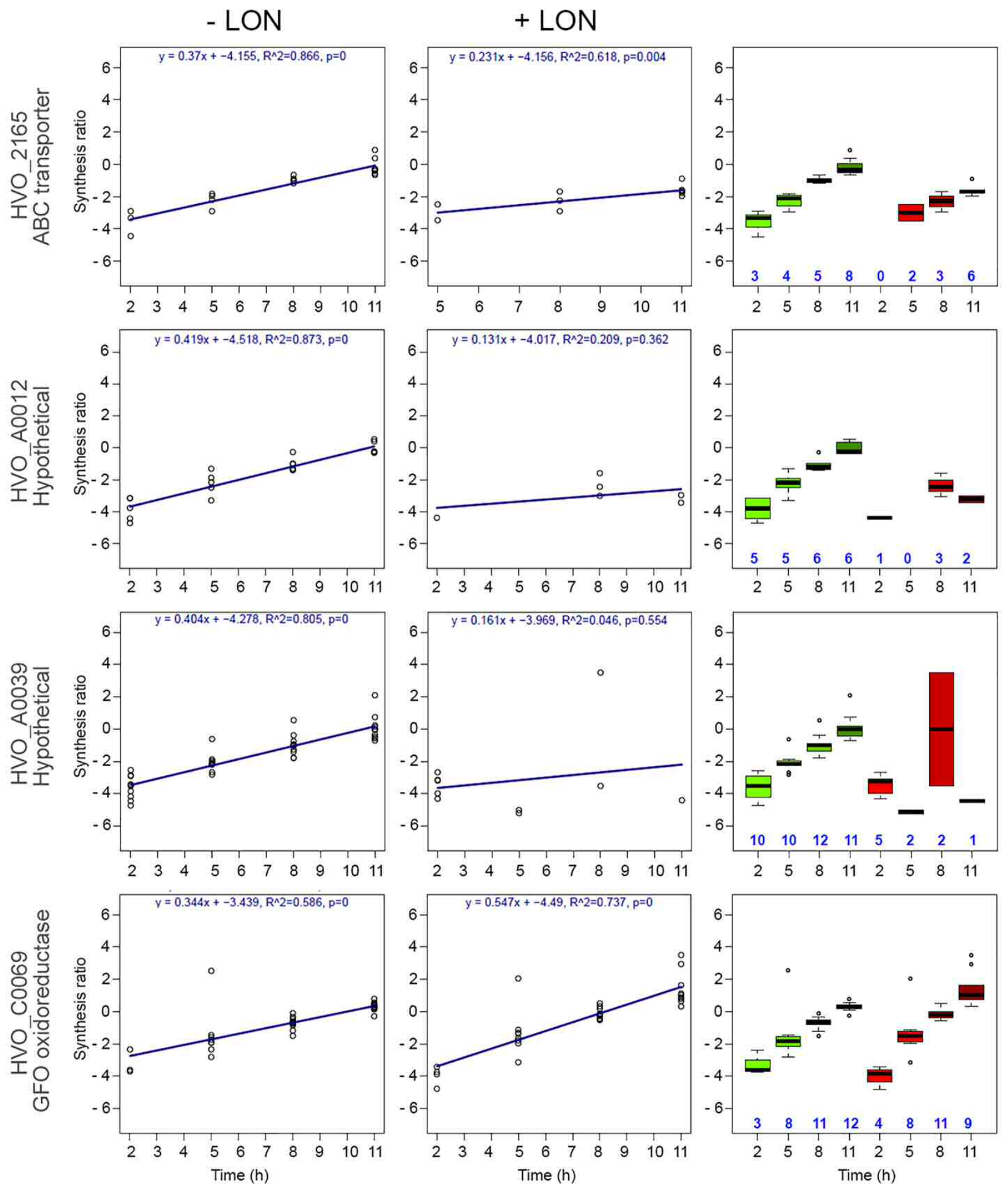

Figure 1. Abundance ratios of proteins with LonB-dependent synthesis. The boxplots and linear regression analysis show the distribution and tendency of the reciprocal abundance ratios $\left({ }^{14} \mathrm{~N} /{ }^{15} \mathrm{~N}\right)$ over time in the \pm Lon conditions for a selected group of proteins that evidenced LonB-dependent synthesis. 
The data was obtained from three biological replicates. In the boxplots, the mean is indicated by horizontal bars, boxes are the upper and lower quartiles and whiskers are 1.5 times the interquartile range. Green boxes: - Lon; red boxes: + Lon. Blue numbers indicate quantified peptides. HVO_2165: ABC-type permease (Lol lipoprotein release factor), HVO_A0012 and HVO_A0039: HY, HVO_C0069: GFO family oxidoreductase.

\subsection{LonB negatively affects a secondary protease/LonB chaperone activity}

A few proteins that were found to be reduced in amount in HVLON3 were stabilized (less degradation) in the + Lon condition. This was the case for carbamoyl-phosphate synthase (HVO_2361) and acyl-CoA dehydrogenase (HVO_2716). We hypothesized that these proteins may be targets of a second (unknown) protease that is negatively affected by Lon. Alternatively, these proteins may be stabilized as a consequence of Lon chaperone activity as suggested in Lee et al. ${ }^{27}$

\subsection{LonB-dependent degradation (endogenous substrates)}

Based on the boxplots and linear regression analysis we divided proteins with differential degradation rates into two groups, depending on whether they were stabilized or preferentially degraded in presence of Lon. Among the latter group, we selected 58 proteins that showed a distinct degradation pattern which consisted in none/very little degradation when the cellular LonB concentration was low (- Lon) and increased their degradation in response to LonB ( + Lon). These proteins were considered as candidate endogenous LonB substrates (Table S4, bold). From this group, 57\% (33/58 proteins) were found in the membrane fraction meaning that they are by some means associated to the cytoplasmic membrane (nearly $64 \%, 21 / 33$, of these proteins were predicted to contain TMS and/or secretion signals). These observations suggest the archaeal-type LonB is involved in the degradation of membrane-associated as well cytoplasmic proteins in $H$. volcanii.

LonB targets belonged to various functional categories including lipid/carotenoid metabolism (PSY, HVO_2524; HMG-CoA synthase, HVO_2419), solute transport (ABC-type transport system ATP-binding 
protein, HVO_2801), transcription regulation (ArsR family, HVO_1552), signal transduction (histidine kinase, HVO_0570), translation (30S ribosomal protein S7, HVO_0354), as well as proteins of unknown function (HVO_0995; HVO_2203; HVO_2770). The wide spectrum of proteins whose degradation is affected by LonB shows that this protease has a central role in $H$. volcanii physiology and reflects that it is an essential protein for this organism. Among the 58 potential substrates, we focused on those that: a. were stabilized in HVLON3 (e.g. PSY; DNA-binding protein HVO_2421); b. had the strongest degradation in presence of LonB (e.g. GNAT family acetyltransferase Pat2; Ribosomal protein S9 HVO_2777; conserved hypothetical protein HVO_2203); c. were related to phenotypes of HVLON3 (e.g. PSY, HMG-CoA synthase); d. and/or were found to interact with LonB in the in vivo crosslinking/immunoprecipitation assay (e.g. histidine kinase HVO_0570; 30S ribosomal proteins S7 HVO_0354 and S13 HVO_2784; SMC-like protein Sph2 HVO_B0118) (Table 2, Table S5). The boxplots and linear regression analysis of some of these targets are shown in Figure 2. 
- LON
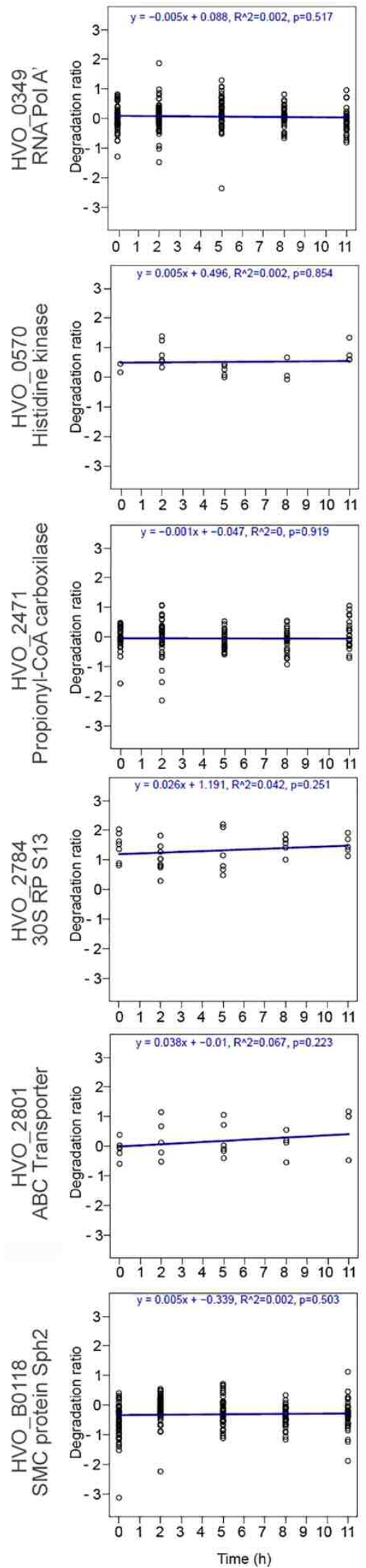

+ LON
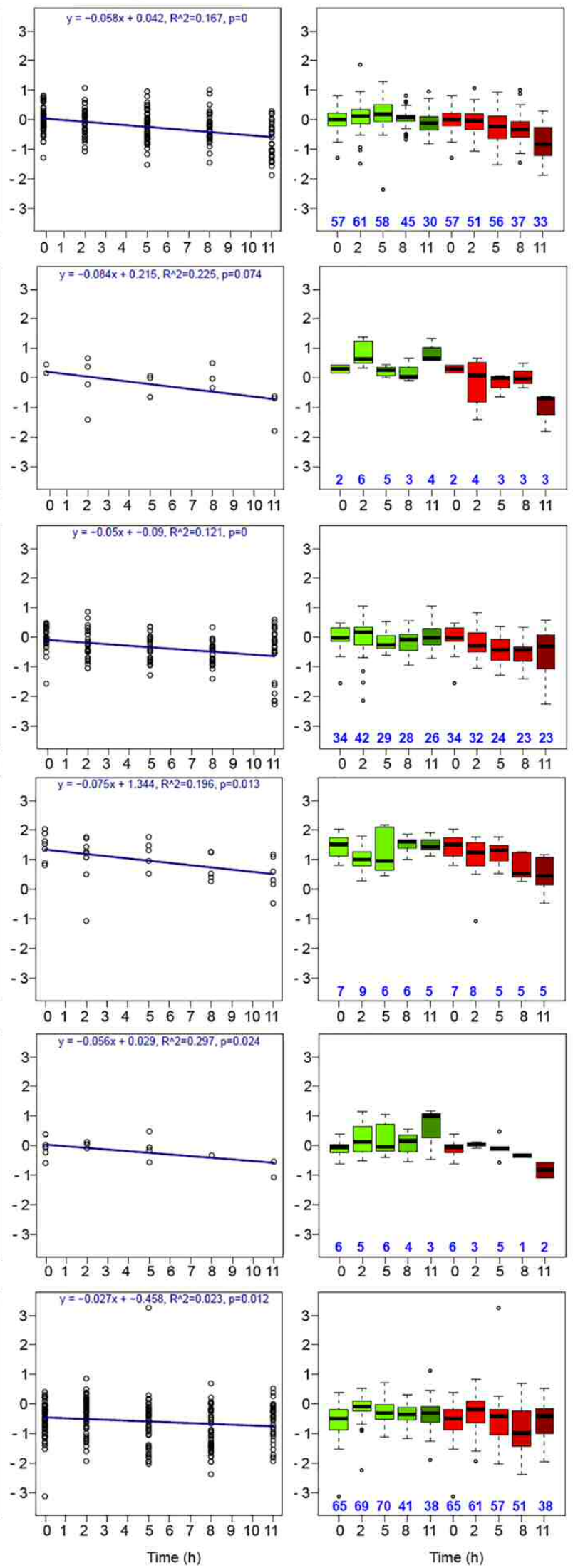
Figure 2. Degradation rates of potential physiological LonB targets. The boxplots and linear regression analysis shows the distribution and tendency of the abundance ratios $\left({ }^{14} \mathrm{~N} /{ }^{13} \mathrm{C}\right)$ over time in the \pm Lon conditions for a selected group of proteins that evidenced LonB-dependent degradation. The data was obtained from three biological replicates. In the boxplots, the mean is indicated by horizontal bars, boxes are the upper and lower quartiles and whiskers are 1.5 times the interquartile range. Green boxes: Lon; red boxes: + Lon. Blue numbers indicate quantified peptides. HVO_0349: RNA pol subunit A', HVO_0570: histidine kinase, HVO_2471: propionyl-CoA carboxylase, HVO_2784: 30S ribosomal protein S13, HVO_2801: ABC-type ATP-binding (amino acids), HVO_B0118: SMC-like protein Sph2.

\section{In vivo degradation of PSY is LonB-dependent}

One of the most noteworthy proteins that showed significant differences in both synthesis ( $p$-value 5.81E05 ) and degradation rates ( $p$-value 1.57E-09) in response to LonB was PSY (Table 2, Table S4), the key enzyme in the carotenoid biosynthesis pathway. Other proteins involved in the mevalonic acid (MVA) pathway, leading to biosynthesis of isoprenoid precursors isopentenyl diphosphate/dimethylallyl diphosphate (IPP/DMAPP) and carotenogenesis, were also differentially affected by LonB in degradation and/or synthesis, including: Hydroxymethylglutaryl-CoA synthase (HMGS, HVO_2419), diphosphomevalonate decarboxylase (HVO_1412), isoprenyl diphosphate synthase (IdsA1, HVO_2725) and phytoene dehydrogenase (PDH, phytoene desaturase, HVO_0817). Figure S7 shows a schematic representation of the MVA and carotenoid biosynthesis pathways with the enzymes affected in degradation (D) and/or synthesis (S) in presence of the LonB protease in H. volcanii.

The boxplots in Figure 3 show the distribution of all calculated degradation and synthesis ratios for PSY for the \pm Lon conditions over time. When LonB was at suboptimal concentrations (- Lon) the ${ }^{14} \mathrm{~N} /{ }^{13} \mathrm{C}$ abundance ratios were stable over time, meaning that this protein was stabilized. On the contrary, when trp was added to the culture and LonB synthesis was stimulated, PSY was rapidly degraded which was evidenced by the drastic decrease in ${ }^{14} \mathrm{~N} /{ }^{13} \mathrm{C}$ abundance ratio in the first time point $(2 \mathrm{~h}$ ) (Figure $3 \mathrm{~A})$. In the next time points $(5,8$ and $11 \mathrm{~h})$ the ratios could not be calculated due to the absence of ${ }^{14} \mathrm{~N}-$ labeled 
peptides. This means that as LonB was synthesized, PSY was degraded so rapidly that after $2 \mathrm{~h}$ the "old protein" $\left({ }^{14} \mathrm{~N}\right)$ could no longer be detected. Thus, these results clearly show that degradation of PSY is LonB-dependent in H. volcanii. HMGS also showed a degradation pattern consistent with a Lon target (Table 2). This enzyme catalyzes the reaction in which Acetyl-CoA condenses with acetoacetyl-CoA to form 3-hydroxy-3-methylglutaryl-CoA (HMG-CoA) and is the second reaction in the mevalonatedependent isoprenoid biosynthesis pathway.

The lon gene is organized as a transcription unit with the sequence HV_0784 encoding the hypothetical protein denoted as Abi related to the CAAX prenyl endopeptidase family. Whether this protein has a functional relevance in $H$. volcanii is not known, moreover, we have constructed a deletion mutant of the $a b i$ sequence which so far did not evidence any differential phenotype compared to the wt (including pigmentation). ${ }^{8}$ Thus, a potential contribution of this protein to PSY turnover can be ruled out.

In parallel to degradation, PSY synthesis was enhanced after LonB expression was stimulated by trp (Figure 3B).
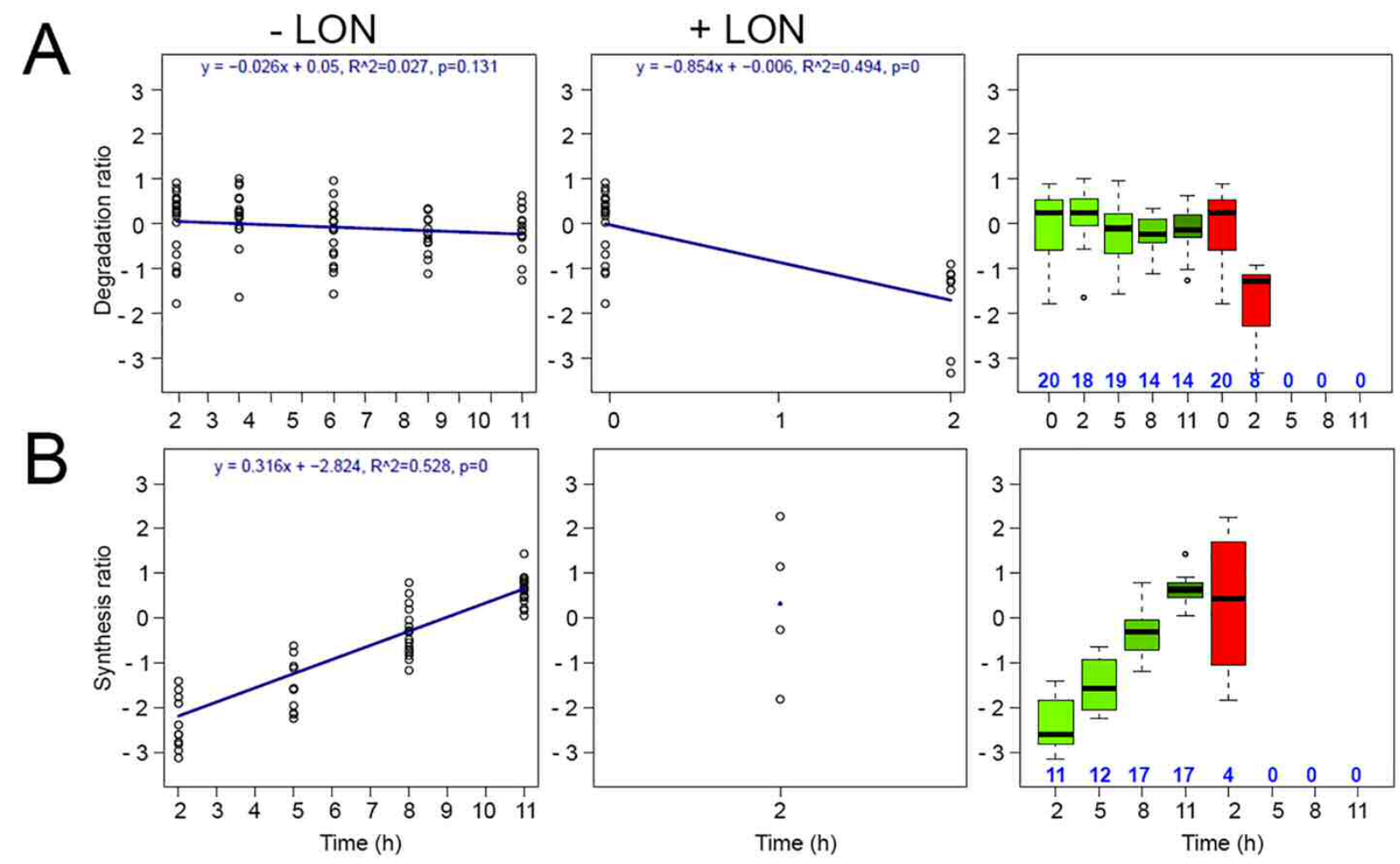
Figure 3. Changes in PSY turnover in response to LonB. The boxplots show the distribution of the degradation (A) and reciprocal synthesis (B) abundance ratios for PSY in \pm Lon over time. The data was obtained from three biological replicates. In the boxplots, the mean is indicated by horizontal bars, boxes are the upper and lower quartiles and whiskers are 1.5 times the interquartile range. Green boxes: - Lon; red boxes: + Lon. Blue numbers indicate quantified peptides.

As complementary strategies to validate that PSY was degraded by LonB, we attempted to determine in vivo degradation by adding puromycin to cultures of HVLON3 in absence and presence of trp, as well as in vitro degradation using recombinant His6PSY in presence of His6Lon or $H$. volcanii membranes as a source of enzyme. PSY protein levels were analyzed over time by Western blotting with anti-HVPSY developed in our laboratory (in vivo/in vitro assays) and anti-His antibodies (in vitro assay). Unfortunately, detection/quantification of PSY reproducibly was not successful, due to the poor quality of the anti-HVPSY antisera (low sensitivity for PSY and high background), and/or the limited amounts of recombinant His6PSY (barely detectable with anti-His antibody). Pull-down assays in $H$. volcanii cells overproducing His6PSY with anti-HVPSY antisera were also unsuccessful.

\section{Stabilization of PSY does not account for the lethality of the lonB mutation}

Accumulation of bctr in $H$. volcanii HVLON3 as a consequence of PSY stabilization likely affects the functionality of the cell membrane which is reflected by a decrease in growth rate compared to the wt strain. ${ }^{8}$ To address this hypothesis directly, we constructed a chimeric $H$. volcanii strain that overexpresses recombinant PSY and grew this strain in presence of different concentrations of trp to induce PSY expression. Overexpression of PSY led to a drastic decrease in growth rate (Figure S8A) and an increase in bctr content (4-fold) (Figure S8B), indicating that the recombinant PSY was functional and excess amounts of bctr severely affected $H$. volcanii physiology.

To investigate whether stabilization of PSY impaired viability of the lon $\mathrm{KO}$ mutants in $H$. volcanii, the PSY gene $(\operatorname{crtB})$ was deleted in the H26 wild type strain by homologous recombination and then, this 
strain was subjected to the pop-in/pop-out protocol to delete the lon gene. After testing around 100 colonies by PCR and Western blotting we were unable to detect clones that had "completely" deleted the lon gene, suggesting that PSY stabilization (and thus betr accumulation) is not the sole/main reason for the indispensability of LonB in $H$. volcanii. This conclusion was supported by the fact that some clones which had amplified a DNA fragment of 400 bp by PCR consistent with the absence of the lonB gene (primers flanking the lon sequence), still synthesized the Lon protein as evidenced by Western blotting (Figure S9). H. volcanii is polyploid and it has been reported that gene conversion leads to genome equalization. ${ }^{28}$ Our results suggest that in this experiment a few cells may have deleted the lon gene in some but not all chromosome copies, which further confirms the essentiality of the LonB protease.

On the other hand, the $\operatorname{crtB}$ gene was successfully deleted from the chromosome of the strain HVLON3 rendering almost all the clones white (unpigmented) after the pop-in/pop-out protocol. The high efficiency of psy KO mutation (nearly $100 \%$ ) in addition to the fact that these mutants showed a higher growth rate than the parental strain HVLON3 (Figure S10) suggests that even though PSY stabilization may not be the sole reason for the lethality of the lon mutation, it severely affects $H$. volcanii growth performance.

\section{DISCUSSION}

This work examined the impact of the membrane-associated LonB protease on the proteome turnover of the extremophilic euryarchaeon $H$. volcanii. To this end, metabolic labeling with ${ }^{14} \mathrm{~N},{ }^{15} \mathrm{~N}$ and ${ }^{13} \mathrm{C}$ was applied to cultures of a $H$. volcanii lonB conditional mutant (HVLON3) strain growing under reduced (trp) and physiological ( + trp) protease content (Figure S1). Although various proteomics-based methods have been applied to study proteolysis in different organisms, ${ }^{29}{ }^{30}$ to the best of our knowledge, no other study has implemented this technology for the search of natural substrates of membrane proteases in prokaryotes. We show that this method was powerful for the identification of various candidate targets of the archaeal Lon protease (see below). 


\section{LonB negatively affects/inhibits translation in $H$. volcanii}

LonB expression globally affected the overall proteome turnover in $H$. volcanii including the synthesis (Table S3) and/or degradation rates (Table S4) of many proteins. A total of 225 proteins displayed differential synthesis rates depending on whether LonB was present at suboptimal (- trp) or physiological

$(+\operatorname{trp})$ levels, many of which were found to change in amount in the conditional HVLON3 mutant ${ }^{16}$ (Table 2) (e.g. hypothetical protein HVO_A0039).

Translation initiation factors (TiF) aIF-2 and aIF2/5B have a key regulatory role in archaeal translation as they stimulate the binding of Met-tRNAi to the ribosomes. ${ }^{31}$ These factors (TiF aIF-2 $\gamma$, HVO_1901 and TiF aIF-5B, HVO_1963) as well as Met-tRNA ligase (HVO_0809) showed significant differences in synthesis and/or degradation (Table S3, S4), and other proteins involved in translation (16 ribosomal proteins, tif2b2, peptide chain release factor aRF-1, 3 aminoacyl-tRNA ligases) diminished their synthesis rate when Lon production was stimulated (Figure S3, Table S3). In addition, in presence of Lon the overall proteome synthesis rate was significantly lower in the membrane fraction (Figure S4). Altogether, these results suggest that Lon is a negative regulator of translation in $H$. volcanii. In E. coli overproduction of the Lon protease inhibits translation by means of the yefM-yoeB toxin-antitoxin (TA) system and a TAindependent pathway. ${ }^{32}$ TA systems occur in prokaryotes (bacteria and archaea) and some of these serve as stress response elements facilitating adaptation of $E$. coli cells to starvation or other adverse conditions. Whether this Lon-dependent mechanism is conserved in archaea remains to be demonstrated. In this study, homologs of the known bacterial TA systems were not identified, however, we cannot rule out the possibility that uncharacterized protein/s (hypothetical) affected by LonB may have TA analogous functions in $H$. volcanii.

\section{LonB targets are membrane-associated and soluble proteins}

The overall proteome degradation rate accelerated when LonB synthesis was stimulated (Figure S5) indicating that the archaeal-type Lon has a key role in controlling the turnover of both membrane- 
associated and soluble proteins in $H$. volcanii. A total of 291 proteins showed differential degradation rates depending on Lon expression (Table S4) and a selected group were notably degraded in presence of Lon, thus a priori, they were considered natural substrates of the archaeal LonB (Table S4, bold). This group included membrane-associated and soluble proteins involved in a variety of cellular processes (lipid/carotenoid metabolism, solute transport, transcription regulation, signal transduction, translation, post-translational modifications) or had unknown functions, which highlights the relevance of LonB in archaeal physiology. Among the list of potential LonB substrates, some stood out either because they were highly stabilized in HVLON3 (e.g. PSY, DNA-binding protein HVO_2421); they displayed the most evident degradation patterns (e.g. PSY, 30S ribosomal proteins S7 and S2, histidine kinase HVO_0570, GTP-binding protein Drg HVO_0911, hypothetical proteins HVO_0995 and HVO_2203) and/or they were related to the phenotypes of HVLON3 (PSY, HMG-CoA synthase) (Table 2). Some of these LonB targets (including 30S ribosomal protein S7 HVO_0354, TrmB family transcription regulator HVO_A0150 and propionyl-CoA carboxylase HVO_2471) and polypeptides involved in the "functional protein complex" of a Lon target (RNA polymerase subunit A HVO_0350) co-precipitated with LonB in pull-down assay meaning that these proteins likely interact with this protease in vivo. This outcome further supports the fact that these proteins are likely natural substrates of LonB. However, some targets with a remarkable Lon-dependent degradation pattern (e.g. PSY) were not detected in the pull-down assays. The inability to detect PSY in association with Lon may be attributed to the low abundance of this protein and/or its rapid degradation in the wt genetic background.

Several transcription factors appeared as candidate Lon substrates (ArsR family HVO_1552; TrmB family HVO_A0150; DNA-binding protein HVO_2421), thus, the effect of Lon on the synthesis of at least some proteins may be a consequence of the degradation of these proteins. The DNA-binding protein HVO_2421 was preferentially degraded in presence of Lon (Table 2) and was stabilized (20 fold) in HVLON3. ${ }^{16}$ This regulator belongs to the HTH_XRE family (Helix-Turn-Helix_Xenobiotic Response Element), which occurs in Bacteria and Archaea. Well-studied members include the lambda phage repressors $\mathrm{Cro} / \mathrm{CI}$ and some have been suggested as potential anti-toxins. ${ }^{33}$ Thus, it is possible that this 
protein may function as a TA system component involved in translation inhibition. Interestingly, a member of the XRE family, ClgR, binds to the lon gene promoter at a conserved motif (GTTCGC-5NGCG) and regulates Lon expression in Streptomyces. ${ }^{34}$ A similar sequence is present in the upstream region of the $H$. volcanii lon gene (GTTCGC-2N-GCG), thus, it will be interesting to confirm whether the HVO_2421 protein binds to this motif to regulate lon expression in $H$. volcanii as it happens in bacteria.

The proteasome $\alpha$ subunit (HVO_1091) stands as a potential LonB substrate (Table S4) and proteasome $\alpha 2$ subunit (HVO_2923) was overrepresented (2 fold) in HVLON3. ${ }^{16}$ It is possible that stabilization of some cytoplasmic proteins in presence of Lon may be a consequence of the negative effect that Lon exerts on this proteolytic complex. At least this seems to be the case for the enzymes carbamoylphosphate synthase (HVO_2361) and acyl-CoA dehydrogenase (HVO_2716) (Table 2) considering that these proteins were overrepresented in a proteasome-activating nucleotidase A (PanA) deletion mutant of H. volcanii $(\Delta p a n A){ }^{12}$

The structural maintenance of $\underline{\text { chromosome }}$ (SMC) protein family participates in essential functions of chromosome dynamics such as DNA repair, chromosome compaction and segregation. ${ }^{35}$ SMC-like protein Sph2 (HVO_B0118) showed preferential degradation in presence of Lon, was overrepresented by 2.3 fold in HVLON3 ${ }^{16}$ and was also found to interact with LonB in the IP assay (Table 2). Members of this family are known targets of ATP-dependent proteases Clp and LonA in Bacillus subtilis. ${ }^{35}$

\section{PSY degradation is LonB-dependent in H. volcanii}

Carotenoids are natural pigments produced by plants and microorganisms. They participate in photosynthesis and function as antioxidants and membrane stabilizers. Haloarchaea thrive in hypersaline environments $(>2 \mathrm{M} \mathrm{NaCl})$ under intense light irradiation and contain carotenoid pigments which account for the orange-red appearance of their colonies. The most abundant is the C50 carotenoid bctr which provides light protection and rigidity to the cell membranes. ${ }^{36}$

The specific synthetic pathway of carotenoids begins with the conversion of two molecules of geranylgeranyl diphosphate (GGPP) into phytoene, the first and colorless carotenoid. This reaction, 
catalyzed by the enzyme PSY, is considered as the rate-limiting step in carotenogenesis and is conserved in all carotenogenic organisms. Haloarchaea encode potential enzymes for this pathway but only a few have been examined experimentally. 3637383940

In this study, $H$. volcanii PSY showed an evident LonB-dependent degradation pattern: it was completely stabilized at reduced Lon concentrations (- trp) and was degraded very quickly as Lon synthesis was induced (+ trp) (Figure 3). This pattern is consistent with the hyperpigmentation phenotype of $H$. volcanii lon mutants ${ }^{8}$ and accounts for the remarkable increase (50-60 fold) in PSY protein concentration in HVLON3. ${ }^{16}$ RT-PCR assays showed that the increase in PSY protein amount in HVLON3 results from post-transcriptional regulation since PSY transcript levels were similar in wt and HVLON3 strains (Figure S11).

So far, attempts to validate Lon-dependent PSY degradation by complementary strategies (in vivo and in vitro assays) were unsuccessful. Unfortunately, a trapping approach with inactivated LonB is not a feasible alternative since LonB is an essential protein in $H$. volcanii and the target protein responsible for lethality has not been identified yet. However, the rapid degradation of PSY immediately after LonB induction makes the involvement of a secondary protease very unlikely. Additionally, the hyperpigmentation phenotype and remarkable increase of PSY protein in the Lon deficient mutant (not accounted by transcription) points to PSY as a direct target of this protease. Another issue in support of this conclusion is that PSY is membrane-associated which may facilitate its degradation by LonB.

The concomitant increase of PSY synthesis as this protein was degraded (Figure 3) suggests a negative feedback regulatory mechanism of the enzyme, probably exerted by the concentration of bctr, the end product of this anabolic route, and/or other related metabolites. Negative feedback regulation of PSY by carotenoid metabolites has been proposed in tomato and carrot ${ }^{41}{ }^{42}$. Figure 4 describes a proposed model for the regulation of PSY in $H$. volcanii based on the results obtained in this work, the genomic context of crtB gene and/or reports by others. In $H$. salinarum the expression of the crtB1 (PSY) and bop (bacteriorhodopsin) genes is regulated by a small zinc finger protein $\mathrm{Brz}^{43}$ encoded by a sequence located upstream the bop gene and in the same orientation. The analysis of haloarchaeal genomes has uncovered a 
family of zinc finger type proteins, which are believed to regulate the expression of their adjacent genes. The $\operatorname{crtB}$ gene is positioned next to a similar sequence (HVO_2523) in $H$. volcanii and in other haloarchaea as well. By extrapolation, we hypothesize that this protein is involved in the transcriptional regulation of $c r t B$ in haloarchaea.

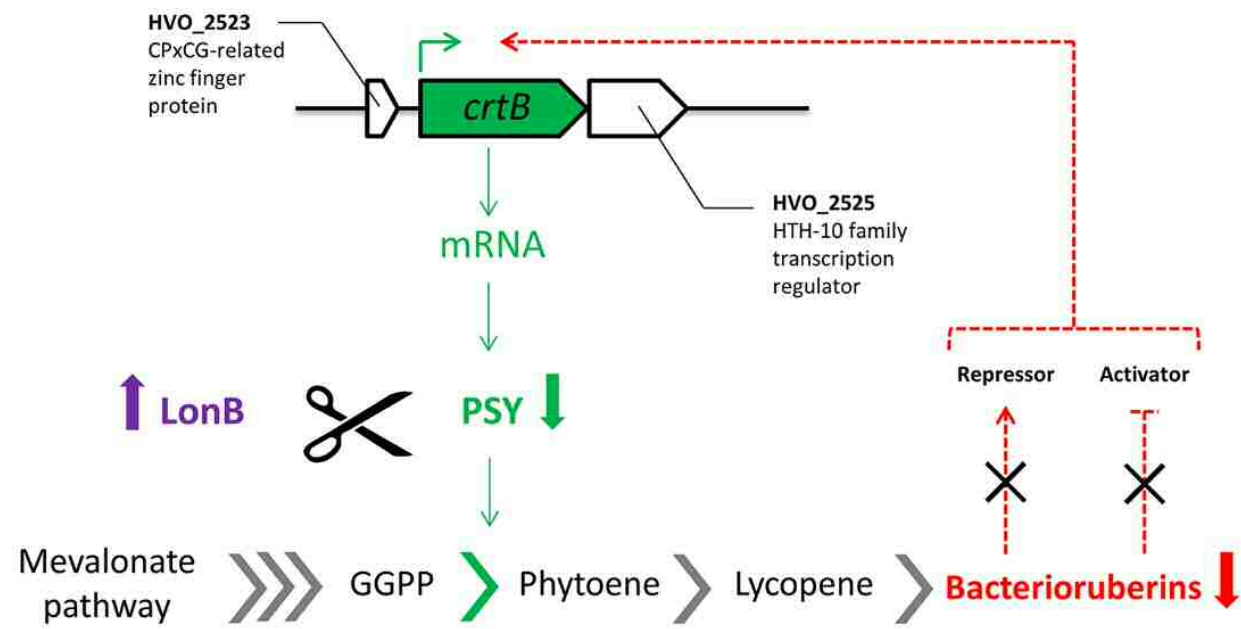

Figure 4. Proposed model for the control of PSY synthesis and degradation by the LonB protease in H. volcanii. PSY is rapidly degraded in presence of LonB which leads to a decrease in the membrane bctr concentration. This, in turn, stimulates PSY synthesis (feed-back loop) by triggering a transcription regulator and/or affecting psy mRNA translation. HVO_2523 and HVO_2525 encode potential transcription regulators.

The molecular mechanisms and factors that regulate carotenogenesis are not clearly understood. Most studies (in plants) have focused on the transcriptional control of biosynthetic enzymes and a large number of transcription factors are known to affect carotenoid accumulation. Those affecting PSY expression include ripening inhibitor (RIN), phytochrome interacting factor 1 (PIF1) and RAP2. ${ }^{44}{ }^{45}$ However, only a few examples of post-transcriptional/post-translational regulators are known. Plant ORANGE (OR) proteins interact with PSY in the chloroplast and stabilize this enzyme via its chaperone activity increasing PSY protein abundance and activity. ${ }^{46} 47$ 
This work shows that LonB is a negative regulator of carotenogenesis in $H$. volcanii by modulating PSY protein turnover (degradation). The remarkable stabilization of PSY under reduced Lon concentrations suggests that Lon-mediated proteolysis may be the main mechanism for regulating the endogenous PSY level in $H$. volcanii, allowing this archaeon to quickly adjust the cellular content of bctr to the varying environmental conditions (including changes in medium salinity and UV light radiation). This hypothesis is also supported by the fact that Lon transcript levels change under suboptimal salt concentrations and UV light exposure (Cerletti et al., 2014). Stabilization or overexpression of PSY negatively affected $H$. volcanii growth rate (Figure S8). This growth defect could be the consequence of bctr accumulation and/or depletion of membrane lipid precursors such as GGPP, affecting the functionality of the cell membrane. Either case, this does not seem to be the sole reason for the lethal phenotype of the lon gene deletion since elimination of this gene in a $\Delta c r t B$ background was impossible (Figure S9) and deletion of $c r t B$ improved but did not completely restore the growth performance of HVLON3 (Figure S10).

The finding that PSY is regulated by LonB-dependent proteolysis provides a novel post-translational mechanism of control for this enzyme. Considering that both the carotenoid biosynthesis pathway and the Lon protease are highly conserved among the three domains of life, it is possible that this regulatory mechanism may operate in other carotenogenic organisms like bacteria, fungi and/or plants.

\section{CONCLUSIONS}

This study shows the impact of the membrane LonB protease on the proteome turnover of the archaeon H. volcanii. To the best of our knowledge this is the first report on the determination of the whole proteome turnover of an archaeon. Using this approach we demonstrated that PSY degradation is LonBdependent and identified novel candidate targets of the archaeal-type Lon protease, some of which were detected associated to Lon in vivo. Regulation of carotenogenesis by means of proteolysis of PSY has not 
been previously reported for any organism, adding a novel mechanism of control to this anabolic route at the post-translational level.

\section{DATA AVAILABILITY}

The mass spectrometry proteomics data have been deposited to the ProteomeXchange Consortium via the Japan Proteome Standard Repository (JPost) with the dataset identifier JPST000291 and will be available after publication.

\section{ACKNOWLEDGEMENTS}

This study was supported by grants PIP-1106-CONICET, PICT-1147-ANPCyT, EXA731/15UNMdP (Argentina) awarded to RDC; MINCyT-BMBF AL/13/02 (Argentina-Germany) awarded to RDC and AP. MC is a postdoctoral fellow and MCF is a PhD student from CONICET (Argentina).

\section{SUPPORTING INFORMATION}

\section{File 1: Supplemental Figures}

Figure S1. Multilabeling approach applied to $H$. volcanii lon deficient strain.

Figure S2. A. LonB synthesis in HVLON3 in absence/presence of trp. B. Incorporation rate of ${ }^{15} \mathrm{~N}$. Figure S3. Distribution of proteins with differential synthesis rates into functional categories. Figure S4. Overview of global protein synthesis rates under suboptimal and physiological LonB concentrations.

Figure S5. Overview of global protein degradation rates under suboptimal and physiological LonB concentrations.

Figure S6. Semi-quantitative RT-PCR analysis of HVO_A0039 mRNA in H. volcanii wt and HVLON3. 
Figure S7. Schematic representation of the MVA and carotenoids biosynthesis pathways showing the enzymes affected in degradation (D) and/or synthesis (S) in presence of the LonB protease in H. volcanii.

Figure S8. Growth and bctr content of H26 pTA-hispsy at different trp concentrations.

Figure S9. Screening of lonB pop-in/pop-out clones in a $H$. volcanii $\Delta c r t B$ strain.

Figure S10. Growth rate of HVLON3 $\triangle c t r B$ mutant.

Figure S11. Semi-quantitative RT-PCR analysis of PSY mRNA in H. volcanii wt and HVLON3.

\section{File 2: Supplemental Tables}

Table S1. List of strains, plasmids and primers used in this study.

Table S2. Effect of LonB on the synthesis rate of amino acid biosynthetic enzymes.

Table S3. List of proteins with differential synthesis in response to LonB.

Table S4. List of proteins that showed differential degradation in response to LonB.

Table S5. Potential substrates identified in co-IP assay.

\section{File 3: QuPe guide}

\section{REFERENCES}

1. Michalik, S.; Bernhardt, J.; Otto, A.; Moche, M.; Becher, D.; Meyer, H.; Lalk, M.; Schurmann, C.; Schlüter, R.; Kock, H., Life and death of proteins: a case study of glucose-starved Staphylococcus aureus. Mol. Cell. Proteomics 2012, 11 (9), 558-570.

2. Trotschel, C.; Albaum, S. P.; Wolff, D.; Schroder, S.; Goesmann, A.; Nattkemper, T. W.; Poetsch, A., Protein turnover quantification in a multilabeling approach: from data calculation to evaluation. Mol. Cell. Proteomics 2012, 11 (8), 512-26.

3. Trotschel, C.; Albaum, S. P.; Poetsch, A., Proteome turnover in bacteria: current status for Corynebacterium glutamicum and related bacteria. Microb Biotechnol 2013, 6 (6), 708-19. 
4. Wallin, E.; von Heijne, G., Genome-wide analysis of integral membrane proteins from eubacterial, archaean, and eukaryotic organisms. Protein Sci. 1998, 7 (4), 1029-38.

5. Gimenez, M. I.; Cerletti, M.; De Castro, R. E., Archaeal membrane-associated proteases: insights on Haloferax volcanii and other haloarchaea. Front Microbiol 2015, 6, 39.

6. Olivares, A. O.; Baker, T. A.; Sauer, R. T., Mechanistic insights into bacterial AAA+ proteases and protein-remodelling machines. Nat. Rev. Microbiol. 2016, 14 (1), 33-44.

7. Maupin-Furlow, J. A.; Gil, M. A.; Humbard, M. A.; Kirkland, P. A.; Li, W.; Reuter, C. J.; Wright, A. J., Archaeal proteasomes and other regulatory proteases. Curr. Opin. Microbiol. 2005, 8 (6), $720-8$.

8. Cerletti, M.; Martinez, M. J.; Gimenez, M. I.; Sastre, D. E.; Paggi, R. A.; De Castro, R. E., The LonB protease controls membrane lipids composition and is essential for viability in the extremophilic haloarchaeon Haloferax volcanii. Environ. Microbiol. 2014, 16 (6), 1779-92.

9. Allers, T.; Ngo, H. P.; Mevarech, M.; Lloyd, R. G., Development of additional selectable markers for the halophilic archaeon Haloferax volcanii based on the leuB and trpA genes. Appl. Environ. Microbiol. 2004, 70 (2), 943-53.

10. Rogers, L. D.; Overall, C. M., Proteolytic post-translational modification of proteins: proteomic tools and methodology. Mol. Cell. Proteomics 2013, 12 (12), 3532-3542.

11. Major, T.; von Janowsky, B.; Ruppert, T.; Mogk, A.; Voos, W., Proteomic analysis of mitochondrial protein turnover: identification of novel substrate proteins of the matrix protease pim1. Mol. Cell. Biol. 2006, 26 (3), 762-76.

12. Kirkland, P. A.; Gil, M. A.; Karadzic, I. M.; Maupin-Furlow, J. A., Genetic and proteomic analyses of a proteasome-activating nucleotidase A mutant of the haloarchaeon Haloferax volcanii. J. Bacteriol. 2008, 190 (1), 193-205.

13. Neher, S. B.; Villén, J.; Oakes, E. C.; Bakalarski, C. E.; Sauer, R. T.; Gygi, S. P.; Baker, T. A., Proteomic profiling of ClpXP substrates after DNA damage reveals extensive instability within SOS regulon. Mol. Cell 2006, 22 (2), 193-204. 
14. Westphal, K.; Langklotz, S.; Thomanek, N.; Narberhaus, F., A trapping approach reveals novel substrates and physiological functions of the essential protease FtsH in Escherichia coli. J. Biol. Chem. 2012, 287 (51), 42962-71.

15. Bhat, N. H.; Vass, R. H.; Stoddard, P. R.; Shin, D. K.; Chien, P., Identification of ClpP substrates in Caulobacter crescentus reveals a role for regulated proteolysis in bacterial development. Mol. Microbiol. 2013, 88 (6), 1083-1092.

16. Cerletti, M.; Paggi, R. A.; Guevara, C. R.; Poetsch, A.; De Castro, R. E., Global role of the membrane protease LonB in Archaea: Potential protease targets revealed by quantitative proteome analysis of a lonB mutant in Haloferax volcanii. J Proteomics 2015, 121, 1-14.

17. Sambrook, J.; Russell, D., Molecular cloning: a laboratory manual. 3rd ed.; New York: Cold Spring Harbor Laboratory Press: 2001.

18. Dyall-Smith, M., The Halohandbook: protocols for haloarchaeal genetics. 2008; Vol. 14.

19. Schluesener, D.; Fischer, F.; Kruip, J.; Rogner, M.; Poetsch, A., Mapping the membrane proteome of Corynebacterium glutamicum. Proteomics 2005, 5 (5), 1317-30.

20. Eng, J. K.; McCormack, A. L.; Yates, J. R., An approach to correlate tandem mass spectral data of peptides with amino acid sequences in a protein database. J. Am. Soc. Mass Spectrom. 1994, 5 (11), 976-89.

21. Pfeiffer, F.; Broicher, A.; Gillich, T.; Klee, K.; Mejia, J.; Rampp, M.; Oesterhelt, D., Genome information management and integrated data analysis with HaloLex. Arch. Microbiol. 2008, 190 (3), 281-99.

22. Kall, L.; Storey, J. D.; MacCoss, M. J.; Noble, W. S., Posterior error probabilities and false discovery rates: two sides of the same coin. J Proteome Res 2008, 7 (1), 40-4.

23. Albaum, S. P.; Neuweger, H.; Franzel, B.; Lange, S.; Mertens, D.; Trotschel, C.; Wolters, D.; Kalinowski, J.; Nattkemper, T. W.; Goesmann, A., Qupe--a Rich Internet Application to take a step forward in the analysis of mass spectrometry-based quantitative proteomics experiments. Bioinformatics 2009, 25 (23), 3128-34. 
24. De Castro, R. E.; Ruiz, D. M.; Gimenez, M. I.; Silveyra, M. X.; Paggi, R. A.; Maupin-Furlow, J. A., Gene cloning and heterologous synthesis of a haloalkaliphilic extracellular protease of Natrialba magadii (Nep). Extremophiles 2008, 12 (5), 677-87.

25. Kaur, H.; Takefuji, M.; Ngai, C.; Carvalho, J.; Bayer, J.; Wietelmann, A.; Poetsch, A.; Hoelper, S.; Conway, S. J.; Möllmann, H., Targeted Ablation of Periostin-Expressing Activated Fibroblasts Prevents Adverse Cardiac Remodeling in Mice. Circul. Res. 2016, 118 (12), 1906-1917.

26. Paggi, R. A.; Madrid, E. A.; D'Alessandro, C. P.; Cerletti, M.; De Castro, R. E., Growth phasedependent biosynthesis of Nep, a halolysin-like protease secreted by the alkaliphilic haloarchaeon Natrialba magadii. Lett. Appl. Microbiol. 2010, 51 (1), 36-41.

27. Lee, I.; Suzuki, C. K., Functional mechanics of the ATP-dependent Lon protease- lessons from endogenous protein and synthetic peptide substrates. Biochim. Biophys. Acta 2008, 1784 (5), 72735.

28. Lange, C.; Zerulla, K.; Breuert, S.; Soppa, J., Gene conversion results in the equalization of genome copies in the polyploid haloarchaeon Haloferax volcanii. Mol. Microbiol. 2011, 80 (3), 666-677.

29. auf dem Keller, U.; Schilling, O., Proteomic techniques and activity-based probes for the systemwide study of proteolysis. Biochimie 2010, 92 (11), 1705-1714.

30. Müller, S. A.; Scilabra, S. D.; Lichtenthaler, S. F., Proteomic Substrate Identification for Membrane Proteases in the Brain. Front Mol Neurosci 2016, 9.

31. Benelli, D.; Londei, P., Translation initiation in Archaea: conserved and domain-specific features. Biochem. Soc. Trans. 2011, 39 (1), 89-93.

32. Christensen, S. K.; Maenhaut Michel, G.; Mine, N.; Gottesman, S.; Gerdes, K.; Van Melderen, L., Overproduction of the Lon protease triggers inhibition of translation in Escherichia coli: involvement of the yefM yoeB toxin antitoxin system. Mol. Microbiol. 2004, 51 (6), 1705-1717. 
33. Makarova, K. S.; Wolf, Y. I.; Koonin, E. V., Comparative genomics of defense systems in archaea and bacteria. Nucleic Acids Res. 2013, 41 (8), 4360-4377.

34. Bellier, A.; Mazodier, P., ClgR, a novel regulator of $c l p$ and lon expression in Streptomyces. J. Bacteriol. 2004, 186 (10), 3238-3248.

35. Mascarenhas, J.; Volkov, A. V.; Rinn, C.; Schiener, J.; Guckenberger, R.; Graumann, P. L., Dynamic assembly, localization and proteolysis of the Bacillus subtilis SMC complex. BMC Cell Biol. 2005, 6, 28.

36. Rodrigo-Banos, M.; Garbayo, I.; Vilchez, C.; Bonete, M. J.; Martinez-Espinosa, R. M., Carotenoids from Haloarchaea and Their Potential in Biotechnology. Mar. Drugs 2015, 13 (9), 5508-32.

37. Falb, M.; Muller, K.; Konigsmaier, L.; Oberwinkler, T.; Horn, P.; von Gronau, S.; Gonzalez, O.; Pfeiffer, F.; Bornberg-Bauer, E.; Oesterhelt, D., Metabolism of halophilic archaea. Extremophiles 2008, $12(2), 177-96$.

38. Dummer, A. M.; Bonsall, J. C.; Cihla, J. B.; Lawry, S. M.; Johnson, G. C.; Peck, R. F., Bacterioopsin-mediated regulation of bacterioruberin biosynthesis in Halobacterium salinarum. J. Bacteriol. 2011, 193 (20), 5658-67.

39. Yang, Y.; Yatsunami, R.; Ando, A.; Miyoko, N.; Fukui, T.; Takaichi, S.; Nakamura, S., Complete Biosynthetic Pathway of the C50 Carotenoid Bacterioruberin from Lycopene in the extremely halophilic archaeon Haloarcula japonica. J. Bacteriol. 2015, 197 (9), 1614-1623.

40. Liu, H.; Han, J.; Liu, X.; Zhou, J.; Xiang, H., Development of pyrF-based gene knockout systems for genome-wide manipulation of the archaea Haloferax mediterranei and Haloarcula hispanica. $J$ Genet Genomics 2011, 38 (6), 261-9.

41. Kachanovsky, D. E.; Filler, S.; Isaacson, T.; Hirschberg, J., Epistasis in tomato color mutations involves regulation of phytoene synthase 1 expression by cis-carotenoids. Proc. Natl. Acad. Sci. 2012, 109 (46), 19021-19026. 
42. Arango, J.; Jourdan, M.; Geoffriau, E.; Beyer, P.; Welsch, R., Carotene hydroxylase activity determines the levels of both $\alpha$-carotene and total carotenoids in orange carrots. Plant Cell 2014, $26(5), 2223-2233$.

43. Tarasov, V. Y.; Besir, H.; Schwaiger, R.; Klee, K.; Furtwangler, K.; Pfeiffer, F.; Oesterhelt, D., A small protein from the bop-brp intergenic region of Halobacterium salinarum contains a zinc finger motif and regulates bop and crtB1 transcription. Mol. Microbiol. 2008, 67 (4), 772-80.

44. Yuan, H.; Zhang, J.; Nageswaran, D.; Li, L., Carotenoid metabolism and regulation in horticultural crops. Horticulture Research 2015, 2, 15036.

45. Zhai, S.; Xia, X.; He, Z., Carotenoids in Staple Cereals: Metabolism, Regulation, and Genetic Manipulation. Front Plant Sci 2016, 7, 1197.

46. Zhou, X.; Welsch, R.; Yang, Y.; Alvarez, D.; Riediger, M.; Yuan, H.; Fish, T.; Liu, J.; Thannhauser, T. W.; Li, L., Arabidopsis OR proteins are the major posttranscriptional regulators of phytoene synthase in controlling carotenoid biosynthesis. Proc Natl Acad Sci U S A 2015, 112 (11), 3558-63.

47. Park, S.; Kim, H. S.; Jung, Y. J.; Kim, S. H.; Ji, C. Y.; Wang, Z.; Jeong, J. C.; Lee, H.-S.; Lee, S. Y.; Kwak, S.-S., Orange protein has a role in phytoene synthase stabilization in sweetpotato. Sci Rep 2016, 6, 33563. 
Table 1. Number of identified, quantified and differential proteins ( \pm Lon) in the proteome turnover assay. Protein identification was performed using SEQUEST algorithm embedded in Proteome Discoverer 1.4 and was based on a minimum of two unique peptides and a minimal false discovery rate of $q$-value $\leq 1 \%$. QuPE platform was used for protein quantification based on ${ }^{14} \mathrm{~N} /{ }^{15} \mathrm{~N}$ and ${ }^{14} \mathrm{~N} /{ }^{13} \mathrm{C}$ abundance ratios. ANOVA was used to determine proteins with differential synthesis/degradation rates between the \pm Lon conditions.

\begin{tabular}{ccccc}
\hline & \multicolumn{2}{c}{ Synthesis } & \multicolumn{2}{c}{ Degradation } \\
\hline & Membrane & Cytoplasm & Membrane & Cytoplasm \\
\hline Identified proteins & 1466 & 1377 & 1242 & 1138 \\
Quantified proteins & 1153 & 1096 & 1107 & 1013 \\
$\begin{array}{c}\text { Differential proteins } \\
(p \leq 0.05)\end{array}$ & $\mathbf{1 5 8}$ & $\mathbf{1 0 0}$ & $\mathbf{1 8 6}$ & $\mathbf{1 6 2}$ \\
\hline
\end{tabular}

Table 2. Prediction of LonB function based on the correlation between synthesis and/or degradation rates upon LonB induction, LonB interacting proteins (this work) and protein abundance changes in the HVLON3 mutant. ${ }^{16}$

\begin{tabular}{|c|c|c|c|c|c|c|}
\hline ID & Protein name & $\begin{array}{l}\text { Degradation } \\
\text { rate +Lon }\end{array}$ & $\begin{array}{l}\text { Synthesis } \\
\text { rate +Lon }\end{array}$ & $\begin{array}{c}\text { IP } \\
\text { assay }\end{array}$ & $\begin{array}{c}\text { Protein } \\
\text { abundance } \\
\text { in HVLON3 }\end{array}$ & Lon effect \\
\hline HVO_0349 & RNA pol subunit $A^{\prime}$ & $+(M),-(C)$ & $+(\mathrm{M})$ & $\mathrm{X}$ & NA & \multirow{14}{*}{$\begin{array}{c}\text { LonB } \\
\text { "substrates": } \\
\text { LonB-dependent } \\
\text { degradation }\end{array}$} \\
\hline HVO_0354 & 30 S ribosomal protein $\mathrm{S7}$ & $+(\mathrm{C})$ & NA & $x$ & NA & \\
\hline HVO_0531 & $\begin{array}{l}\text { ABC-type permease } \\
\text { (sugar) }\end{array}$ & $+(\mathrm{M})$ & NA & & NA & \\
\hline HVO_0570 & Histidine kinase & $+(\mathrm{M})$ & NA & $x$ & NA & \\
\hline HVO_0908 & $\mathrm{CHY}$ & $+(\mathrm{M})$ & NA & & NA & \\
\hline HVO_0911 & GTP-binding protein Drg & $+(\mathrm{C})$ & $+(\mathrm{M}),+(\mathrm{C})$ & & NA & \\
\hline HVO_0995 & $\mathrm{CHY}$ & $+(\mathrm{M})$ & NA & & NA & \\
\hline HVO_1145 & $\begin{array}{l}30 \mathrm{~S} \text { ribosomal protein } \\
\text { S1e }\end{array}$ & $-(M),+(C)$ & - (M) & $\mathrm{x}$ & NA & \\
\hline HVO_1332 & $\mathrm{CHY}$ & $+(\mathrm{C})$ & NA & & $\begin{array}{l}\text { Increased } \\
\times 2.4(C)\end{array}$ & \\
\hline HVO_1387 & Enoyl-CoA hydratase & $+(\mathrm{M})$ & NA & & NA & \\
\hline HVO_1821 & $\begin{array}{l}\text { GNAT family } \\
\text { acetyltransferase Pat2 }\end{array}$ & $+(C)$ & NA & & NA & \\
\hline HVO_2015 & $\mathrm{CHY}$ & $-(M),+(C)$ & $-(M),-(C)$ & $\mathrm{x}$ & $\begin{array}{c}\text { Increased } \\
\times 1.6(\mathrm{M}), \mathrm{x} \\
1.4 \text { (C) }\end{array}$ & \\
\hline HVO_2203 & $\mathrm{CHY}$ & $+(\mathrm{M})$ & NA & & NA & \\
\hline HVO_2402 & Glycine dehydrogenase & $+(\mathrm{M})$ & NA & & $\begin{array}{l}\text { Increased } \\
\times 1.5(\mathrm{M})\end{array}$ & \\
\hline
\end{tabular}




\begin{tabular}{|c|c|c|c|c|c|c|}
\hline HVO_2419 & HMG-CoA synthase & $+(\mathrm{C})$ & $+(\mathrm{C})$ & & NA & \\
\hline HVO_2421 & DNA-binding protein & $+(C)$ & NA & & $\begin{array}{c}\text { Increased } \\
\times 22(C)\end{array}$ & \\
\hline HVO_2452 & $\begin{array}{l}\text { Ribonucleoside- } \\
\text { diphosphate reductase }\end{array}$ & $+(\mathrm{M}),-(\mathrm{C})$ & - (M) & $x$ & $\begin{array}{c}\text { Increased } \\
\times 1.2(\mathrm{M}) \\
\end{array}$ & \\
\hline HVO_2471 & $\begin{array}{l}\text { Propionyl-CoA } \\
\text { carboxylase }\end{array}$ & $+(\mathrm{M})$ & NA & & $\begin{array}{l}\text { Reduced } \\
\mathrm{x}-1.2(\mathrm{M})\end{array}$ & \\
\hline HVO_2486 & $\begin{array}{l}\text { Propionyl-CoA } \\
\text { carboxylase }\end{array}$ & $+(\mathrm{M}),-(\mathrm{C})$ & $+(\mathrm{M}),+(\mathrm{C})$ & & $\begin{array}{c}\text { Increased } \\
\times 1.2(C) \\
\end{array}$ & \\
\hline HVO_2524 & Phytoene synthase & $+(\mathrm{M})$ & $+(\mathrm{M})$ & & $\begin{array}{c}\text { Increased } \\
\times 50(\mathrm{M})\end{array}$ & \\
\hline HVO_2552 & $\begin{array}{l}30 \mathrm{~S} \text { ribosomal protein } \\
\text { S4e }\end{array}$ & $+(C)$ & NA & & NA & \\
\hline HVO_2777 & $30 \mathrm{~S}$ ribosomal protein $\mathrm{S9}$ & $-(\mathrm{M}),+(\mathrm{C})$ & NA & $x$ & NA & \\
\hline HVO_2782 & $\begin{array}{l}30 \text { S ribosomal protein } \\
\text { S11 }\end{array}$ & $-(M),+(C)$ & NA & $x$ & $\begin{array}{l}\text { Reduced } \\
\mathrm{x}-2.8(\mathrm{M})\end{array}$ & \\
\hline HVO_2784 & $\begin{array}{l}30 \text { S ribosomal protein } \\
\text { S13 }\end{array}$ & $+(C)$ & NA & $x$ & NA & \\
\hline HVO_2801 & $\begin{array}{l}\text { ABC-type ATP-binding } \\
\text { (amino acids) }\end{array}$ & $+(\mathrm{M})$ & NA & & NA & \\
\hline HVO_A0150 & $\begin{array}{l}\text { TrmB transcription } \\
\text { regulator }\end{array}$ & $+(C)$ & NA & $x$ & $\begin{array}{c}\text { Reduced } \\
\mathrm{x}-1.8(\mathrm{M})\end{array}$ & \\
\hline HVO_A0207 & $\begin{array}{l}\text { CRISPR-associated } \\
\text { protein Cas7 }\end{array}$ & $+(\mathrm{M}),-(\mathrm{C})$ & $+(M),+(C)$ & $x$ & $\begin{array}{l}\text { Reduced } \\
\mathrm{x}-1.1(\mathrm{C}) \\
\end{array}$ & \\
\hline HVO_B0118 & SMC-like protein Sph2 & $+(C)$ & $+(\mathrm{M}),+(\mathrm{C})$ & & $\begin{array}{l}\text { Increased } \\
\times 2.3(\mathrm{M})\end{array}$ & \\
\hline HVO_B0151 & $\begin{array}{l}\text { NikR transcription } \\
\text { regulator }\end{array}$ & $+(\mathrm{C})$ & NA & & ND & \\
\hline HVO_0795 & $\begin{array}{l}\text { Transcription initiation } \\
\text { factor Tfb6 }\end{array}$ & NA & $+(C)$ & & $\begin{array}{l}\text { Reduced } \\
x-20(C)\end{array}$ & \multirow{11}{*}{$\begin{array}{l}\text { LonB-dependent } \\
\text { synthesis }\end{array}$} \\
\hline HVO_1134 & $\mathrm{CHY}$ & - (M) & $-(\mathrm{M}),-(\mathrm{C})$ & & $\begin{array}{c}\text { Increased } \\
\times 2 \text { (C), } \times 3 \\
\text { (M) }\end{array}$ & \\
\hline HVO_1240 & $\mathrm{CHY}$ & NA & - (M) & & $\begin{array}{l}\text { Increased } \\
\times 2.4(\mathrm{M})\end{array}$ & \\
\hline HVO_2163 & $\begin{array}{l}\text { ABC-type ATP-binding } \\
\text { (lipoprotein) }\end{array}$ & NA & - (M) & & $\begin{array}{c}\text { Increased } \\
\times 2(\mathrm{M})\end{array}$ & \\
\hline HVO_2165 & $\begin{array}{l}\text { ABC-type permease } \\
\text { (lipoprotein) }\end{array}$ & NA & - (M) & & $\begin{array}{l}\text { Increased } \\
\times 7(\mathrm{M})\end{array}$ & \\
\hline HVO_2606 & PQQ repeat protein & NA & $-(M)$ & & $\begin{array}{l}\text { Increased } \\
\times 2.3(\mathrm{M})\end{array}$ & \\
\hline HVO_A0012 & HY & NA & $-(C)$ & $x$ & $\begin{array}{c}\text { Increased } \\
\times 20 \text { (C) }\end{array}$ & \\
\hline HVO_A0039 & HY & NA & - (M) & & $\begin{array}{c}\text { Increased } \\
\times 95-320 \\
\text { (M) }\end{array}$ & \\
\hline HVO_A0406 & $\mathrm{CHY}$ & NA & $-(M)$ & & $\begin{array}{l}\text { Increased } \\
\times 3.6(\mathrm{M}) \\
\end{array}$ & \\
\hline HVO_A0487 & $\begin{array}{l}\text { Cobyrinic acid a,c- } \\
\text { diamide synthase }\end{array}$ & NA & $-(M)$ & & $\begin{array}{c}\text { Increased } \\
\times 11(\mathrm{M})\end{array}$ & \\
\hline HVO_C0069 & GFO oxidoreductase & NA & $+(\mathrm{M})$ & & Reduced & \\
\hline
\end{tabular}




\begin{tabular}{|c|c|c|c|c|c|}
\hline & & & & $x-2(M)$ & \\
\hline HVO_1401 & $\begin{array}{l}\text { ABC-type substrate } \\
\text { binding (sugar) }\end{array}$ & - (C) & NA & $\begin{array}{l}\text { Reduced } \\
\mathrm{x}-1.5 \text { (C) }\end{array}$ & \multirow{4}{*}{$\begin{array}{c}\text { LonB negatively } \\
\text { affects a } \\
\text { secondary } \\
\text { protease/ } \\
\text { LonB chaperone } \\
\text { activity }\end{array}$} \\
\hline HVO_1407 & HTH domain & - (C) & NA & $\begin{array}{l}\text { Reduced } \\
\mathrm{x}-1.7 \text { (C) }\end{array}$ & \\
\hline HVO_2361 & $\begin{array}{l}\text { Carbamoyl-phosphate } \\
\text { synthase }\end{array}$ & $-(C)$ & NA & $\begin{array}{c}\text { Reduced } \\
x-2 \text { (C) }\end{array}$ & \\
\hline HVO_2716 & Acyl-CoA dehydrogenase & $+(\mathrm{M}),-(\mathrm{C})$ & NA & $\begin{array}{c}\text { Reduced } \\
x-2(C)\end{array}$ & \\
\hline
\end{tabular}

Subcellular fraction: M (membrane), C (cytosol).

Relative protein abundance in HVLON3 (reduced LonB concentration) vs wt. ND: not detected; NA: not affected in the experimental conditions used.

$(-) /(+)$ : reduced/increased synthesis or degradation in the + Lon condition.

$\mathrm{X}$ : LonB interacting protein, $\mathrm{CHY}$ : conserved hypothetical protein, HY: hypothetical protein. 


\section{For TOC Only}

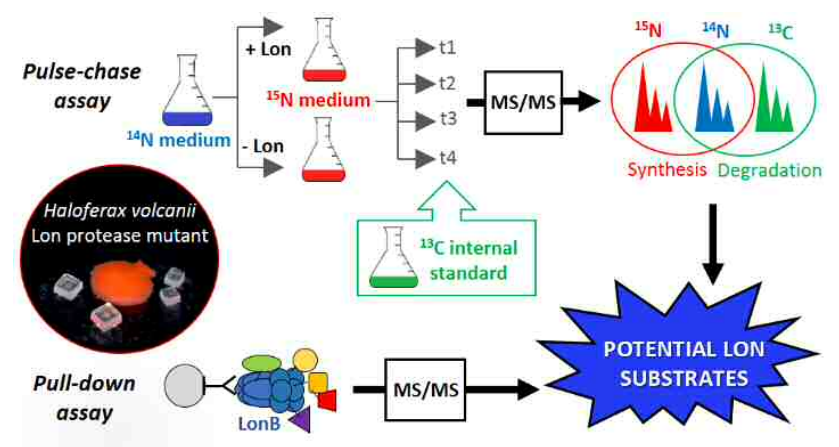

